\title{
The Impact of Fiscal Policy on Non-Oil GDP in Saudi Arabia
}

Fakhri J. Hasanov, Nader AlKathiri, Saad A. Alshahrani and Ryan Alyamani 


\section{Acknowledgments}

The authors accept sole responsibility for any errors and omissions. The views expressed in this paper are the authors' and do not necessarily represent the views of their affiliated institutions. Also, we are grateful to the Ministry of Finance for providing fiscal data. We also thank Fatih Karanfil and Marzio Galeotti and the participants of the KAPSARC workshop, Macroeconomic Stability, and Diversification in Oil-Based Economies, for their comments and suggestions.

\section{About KAPSARC}

The King Abdullah Petroleum Studies and Research Center (KAPSARC) is a non-profit global institution dedicated to independent research into energy economics, policy, technology and the environment across all types of energy. KAPSARC's mandate is to advance the understanding of energy challenges and opportunities facing the world today and tomorrow, through unbiased, independent, and high-caliber research for the benefit of society. KAPSARC is located in Riyadh, Saudi Arabia.

This publication is also available in Arabic.

\section{Legal Notice}

(C) Copyright 2020 King Abdullah Petroleum Studies and Research Center ("KAPSARC"). This Document (and any information, data or materials contained therein) (the "Document") shall not be used without the proper attribution to KAPSARC. The Document shall not be reproduced, in whole or in part, without the written permission of KAPSARC. KAPSARC makes no warranty, representation or undertaking whether expressed or implied, nor does it assume any legal liability, whether direct or indirect, or responsibility for the accuracy, completeness, or usefulness of any information that is contained in the Document. Nothing in the Document constitutes or shall be implied to constitute advice, recommendation or option. The views and opinions expressed in this publication are those of the authors and do not necessarily reflect the official views or position of KAPSARC. 


\section{Key Points}

The impact of fiscal policy on non-oil gross domestic product (GDP) in Saudi Arabia is examined from 1989 to 2018. This covers the low oil price period.

Holding other factors constant,

- a $1 \%$ increase in the government's current and capital expenditure led to a $\mathbf{0 . 2 5 \%}$ and a $\mathbf{0 . 0 2 \%}$ increase, respectively, in non-oil GDP in the long run. The estimated short-run elasticities of the former and latter are $\mathbf{0 . 1 3 \%}$ and $\mathbf{0 . 0 1 \%}$, respectively. However, derived multipliers indicate that an additional 10 Saudi riyals (SAR) increase in current and capital spending led to 4.5 SAR and 5.6 SAR increases, respectively, in non-oil GDP in the long run. This 10 SAR increase also creates respectivel 2.8 SAR and 1.8 SAR additional non-oil GDP increases in the short run.

- a $1 \%$ increase in non-oil labor and non-oil capital increases non-oil GDP by $0.51 \%$ and $0.26 \%$, respectively, on average, in the long run.

No evidence was found of a structural change in the relationship between non-oil GDP and fiscal indicators that could have been caused by the recent decline in oil prices.

Policy insights that can be drawn from this study to increase the positive effect of government expenditures on non-oil economic development are as follows:

- If the government gives the private sector a bigger role in financing and executing infrastructure projects, it would realize its capital expenditure savings. The government could use part of these savings to support the development of the non-oil economy. Government expenditures can have a larger positive growth effect if they are directed toward projects that foster non-oil private investment and non-oil employment.

- Additional fiscal reforms could further improve the efficiency of the government's capital expenditure.

- The government could consider continued improvements to the Kingdom's business environment for domestic and foreign investment, as well as improving the country's economic and social infrastructure and legislative frameworks. This would help to encourage more domestic and foreign investment, among other positive externalities.

- Further involvement of the private sector in investment and job creation projects would enhance its role in boosting non-oil economic growth. Attracting more foreign direct investment would also enhance non-oil capital stock and help encourage technological advancement. 


\section{Summary}

A

clear objective of Saudi Vision 2030, the strategic roadmap for the future of the Kingdom of Saudi Arabia, is to put the non-oil sector at the heart of the country's economic development. The vision realization programs (VRPs), such as the National Transformation Program and Fiscal Balance Program (FBP), have established initiatives and targets to help develop the non-oil sector. It is important, then, to explore the role fiscal policy can play in developing the country's non-oil sector.

To this end, this study aims to assess the impact of the government's budget expenditures on Saudi Arabia's non-oil sector over an extended period, in which the recent oil price drop is included. This analysis could help to derive insights for fiscal authorities.

We applied cointegration and equilibrium correction modeling as well as a structural break test to the Saudi Arabian annual time series data from 1989-2018. We found that the government's current and capital expenditures have statistically significant positive impacts on the non-oil gross domestic product (GDP) in both the long and short run. Holding other factors constant, a $1 \%$ increase in the government's current and capital expenditure leads to about a $\mathbf{0 . 2 5 \%}$ and a $\mathbf{0 . 0 2 \%}$ increase, respectively, in non-oil GDP in the long run.

The economic growth effect of fiscal spending depends on its effectiveness and efficiency. One of the findings of previous studies is that there is room for efficiency improvements at various stages of government spending, in particular capital expenditure in Saudi Arabia and other GCC and developing economies (Al-Faris 2002; Joharji and Starr 2010; Espinoza et al. 2013; Alshahrani and Alsadiq 2014; Eid and Awad 2017; Al-Arbi et al. 2018; IMF 2019). This point is also highlighted in
Vision 2030's Fiscal Balance Program (FBP 2019). Additionally, a significant portion of the capital goods and related services consumed in Saudi Arabia is imported from abroad and this leakage reduces the magnitude of the impact of capital expenditure.

For the short-run relationship, we found that a 1 percentage point increase in the contemporaneous growth rates of Saudi Arabia's current and capital expenditure is associated with a $\mathbf{0 . 1 3}$ and a $\mathbf{0 . 0 1}$ percentage point increase, respectively, in non-oil GDP growth. We also found that a $1 \%$ increase in non-oil labor and non-oil capital increases non-oil GDP by, on average, $0.51 \%$ and $0.26 \%$, respectively, in the long run. Furthermore, we did not find a break in either the long-run or short-run relationships that non-oil GDP establishes with government expenditures. This could be caused by the oil price decline in recent years.

The findings of this study introduce several policy recommendations for fiscal policy measures to help develop Saudi Arabia's non-oil sector. These include the following:

First, capital and labor have large positive impacts on non-oil GDP in the long run. This implies that government expenditure can have a larger positive impact if it is directed toward the projects that help expand non-oil private investment and employment. As gleaned from recent budget documents, the government has already begun to move in that direction, most notably through capitalizing on the efforts of the Center of Spending Efficiency, which has helped to curb inefficient spending. One of Saudi Vision 2030's realization programs is entirely dedicated to the development of human capital. Accordingly, the government might want to further consider focusing on developing human capital, including investing in education, vocational training and capacity building. 
Second, since 2017, the government has embarked on several reforms of fiscal planning, public finance management, and budget execution, all of which have helped improve the efficiency of government expenditure. However, more reforms are needed in order to further improve the efficiency of government expenditure, especially capital spending. To this end, the government recently established the Center for Spending Efficiency and introduced a new public procurement system. The positive effects of the public financial management reforms will become more evident in the upcoming years.

Third, it would be advisable for the government to continue improving the Kingdom's business environment, as well as its economic, social infrastructures, and legislative frameworks. This would help induce more domestic and foreign investment, among other positive externalities.

Fourth, the further involvement of the private sector in investment and job creation projects would support the development of the non-oil sector. Attracting more foreign direct investment would also enhance non-oil capital stock and help bring about further technological advancements. More foreign investment would also help the Kingdom to diversify its economy.
Fifth, the government may wish to continue to reprioritize its spending to promote the development of the country's non-oil economy. It could consider increasing local content and reducing imported goods and services. Reducing the country's fiscal deficit, mainly by increasing non-oil revenues without hurting non-oil activities, would enhance the country's fiscal position. This measure could be supported by the recently-implemented Ministry of Finance's medium-term macro-fiscal framework and would allow the government to increase its efficient expenditure while maintaning fiscal sustainability over the long run. Some of the Kingdom's recent structural reforms are helpful in this regard, but more are needed. 


\section{Introduction}

A clear objective of Saudi Vision 2030, the strategic roadmap for the future of the Kingdom of Saudi Arabia, is to put the non-oil sector at the heart of the country's economic development. The vision realization programs (VRPs), such as the National Transformation Program and Fiscal Balance Program (FBP), have established initiatives and targets to help develop the non-oil sector. It is important, then, to explore the role fiscal policy can play in developing the country's non-oil sector.

Oil revenues are volatile and uncertain, making fiscal planning problematic in oil-dependent countries, including Saudi Arabia. Volatile oil revenues often lead to pro-cyclical fiscal policies by overspending in periods of high oil prices and spending much less when prices fall. Volatile government expenditure has social and economic costs, it adds uncertainty to the investment climate, and it challenges the capacity of the private sector to make long-term investments. Resource revenue booms often lead to an accelerated expansion of government expenditure that could prove difficult to sustain in a low oil price environment (Frankel 2011). Pieschacón (2012) shows that prudent fiscal discipline can improve welfare by smoothing consumption in the face of oil price shocks.

There are five main reasons why it is important to investigate the effects of fiscal policy on the development of Saudi Arabia's non-oil sector. First, fiscal policy is both theoretically and empirically established as one of the key macroeconomic policies that can promote economic growth (Keynes 1936; Rubinson 1977; Ram 1986; Sorsa 1999; Fasano and Wang 2001, among others). Second, fiscal policy has a dominant position in resource-rich economies and is usually complemented by other policies (Looney 1986, 1989a, 1989b; Al-Hamidy 2012; Hasanov et al. 2018; Sturm et al. 2009; Wakeman-Linn et al.
2002). Third, the majority government-owned oil company, Saudi Aramco, is the sole owner of the country's oil infrastructure. Most of its revenues are transferred to the government, and it has an imperative role in distributing its income from oil sales to the wider economy (Al-Yousef 2000; Al-Hamidy 2012; Alshahrani and Al-Sadiq 2014; Mallakh 2015). Fourth, fiscal policy is almost the only bridge that can link Saudi Arabia's oil sector revenues to its non-oil economy, as other channels such as financial markets are still in the development phase (WB 1988; Looney 1989b; Al-Yousef 2000; Fasano and Wang 2001; Al-Hamidy 2012). Finally, the government's fiscal initiatives also play a role in forming aggregate demand in the economy and fostering long-term growth. They include cash transfers (Citizen Account Program), among other subsidies, private sector development, including soft loans to boost economic growth, the implementation of giga projects and Vision 2030 realization programs (see Looney 1986; Fasano and Wang 2001, among others).

Two further points inspired us to conduct this study. The first was to check for a possible break in the relationship between the non-oil sector and government expenditure. This point is associated with the fact that government revenues, and thus expenditures, depend heavily on oil revenues, and thereby oil prices, with the latter declining since 2012, increasingly so since 2014 . Government oil export revenues followed the price dynamics of Arabian light closely over the period this paper investigates: 1989-2018. The share of oil export revenues, which mirror oil price dynamics, in total revenues grew from $66.2 \%$ in 1989 to a high of $92.6 \%$ in 2011 , before declining along with oil prices since then. Corresponding changes in government expenditures due to declining oil prices necessitate checking structural breaks in the impact of declining 
oil prices on the non-oil sector. Testing for a possible structural break is important in order for the estimation results to be used for policy analysis and forecasting. A structural break can create instability in the estimated parameters, which would result in misleading numerical policy suggestions (Hendry 2018; Castle and Hendry 2014; Castle et al. 2015; Perron 2006; Chow 1960; Gujarati 1970).

The second point that motivated us to conduct this study is that earlier empirical studies found a positive impact of fiscal policy, especially government expenditures, on the development of Saudi Arabia's non-oil sector. These studies are documented in the literature review section. We empirically analyze whether this still holds true when considering the most recent data. If yes, then is it true in the long run, in the short run, or both, and what are the magnitudes of the numerical impacts?

Thus, our research aims to investigate the impact of the government's current and capital budget expenditures on Saudi Arabia's non-oil sector over an extended period to derive insights that might be useful for policymaking. ${ }^{1}$

Our study addresses the following research questions:

Are there any short- and long-run impacts of the government's current and capital expenditure on Saudi Arabia's non-oil GDP?

If there is a long-run relationship, how much time is needed for non-oil GDP to adjust back to this relationship from the short-run disequilibrium?

Does the oil price decline in recent years cause a break in the impact of the government's current and capital expenditure on non-oil GDP?
We apply cointegration and error correction modeling as well as structural break tests to the Saudi Arabian data in the augmented production function framework. We find that both the government's current and capital expenditures have statistically significant positive impacts on non-oil GDP, in both the long and short run. We also find that non-oil labor and capital have statistically significant positive impacts on non-oil GDP. Lastly, we find no break in either the long-run or short-run relationships that non-oil GDP establishes with government expenditures. This could be caused by the oil price decline in recent years.

This study introduces several recommendations that could be useful for fiscal policy measures and for promoting non-oil economic activities. Such policy recommendations could also help to achieve some of the fiscal and economic objectives of Vision 2030.

This research contributes to the existing literature in the following ways. First, it investigates the non-oil growth effects of government budget expenditures over a longer period than has previously been evaluated, including the recent low oil-price environment. Second, it takes the production function concept as its theoretical framework, unlike earlier studies, some of which lack any theoretical underpinning. Third, it conducts robustness checks to a greater extent than previously undertaken by applying different estimation and testing methods and making a small sample bias correction.

Fourth, it conducts a structural break analysis to determine whether there is econometric support for the structural break. Fifth, we hope this study encourages other researchers to conduct the same type of analysis for other oil-exporting developing countries, including GCC countries, Russia, and Mexico. 


\section{Introduction}

The rest of the paper is structured as follows. The next section presents a background of the Saudi Arabian economy. Section 3 presents the literature review, and it is followed by the theoretical foundation of the research in section 4 . Section 5 describes the data used in the empirical analysis.
The econometric methods of the research are given in section 6 , while section 7 documents the findings of the empirical analysis. Section 8 conducts a structural break analysis. Section 9 discusses the findings, and section 10 concludes the research and recommends some policy insights. 


\section{Background: The Saudi Arabian Economy}

The Saudi Arabian economy is dependent on oil, a non-renewable natural resource that generates most of its export revenues. The government of Saudi Arabia owns the country's oil reserves and uses revenues generated from those reserves to finance government expenditure. As a result, the country's prosperity is highly linked to the revenues from the sales of oil. From 2009 to 2018, oil exports averaged roughly $80 \%$ of total government revenues.

Economic diversification would reduce Saudi Arabia's dependence on oil through the development of non-oil sectors that are less volatile, more sustainable, and could generate more jobs than the oil sector does currently. This would help the economy to absorb the growing number of nationals entering the labor market each year. This is why, since 1970, economic diversification has remained one of the main strategic objectives for Saudi Arabia, with the aim of decoupling the country's economy from its dependence on oil revenues and helping to create more jobs for its citizens. However, as of
2018 , oil exports still account for $79 \%$ of total exports and continue to be the main source of financing government expenditure.

Government expenditure plays a vital role in the Saudi economy. In 2018, it represented $36 \%$ of total GDP and $64 \%$ of non-oil GDP. The government's capital expenditure (such as investments in physical and human capital) and current expenditure (such as wages and salaries) create demand for goods and services in the economy. The private sector is largely dependent on government contracts and projects, which provide high-return low-risk investments (Callen et al. 2014). Additionally, current expenditure raises household incomes, leading to increased demand for (mostly imported) goods and services from the private sector. Figure 1 shows the co-movement of the growth rates of government expenditure and non-oil GDP in Saudi Arabia. It can therefore be assumed that, based on historical trends and no change in policies, any reduction in the former could negatively impact the latter.

Figure 1. Government expenditure and non-oil GDP growth.

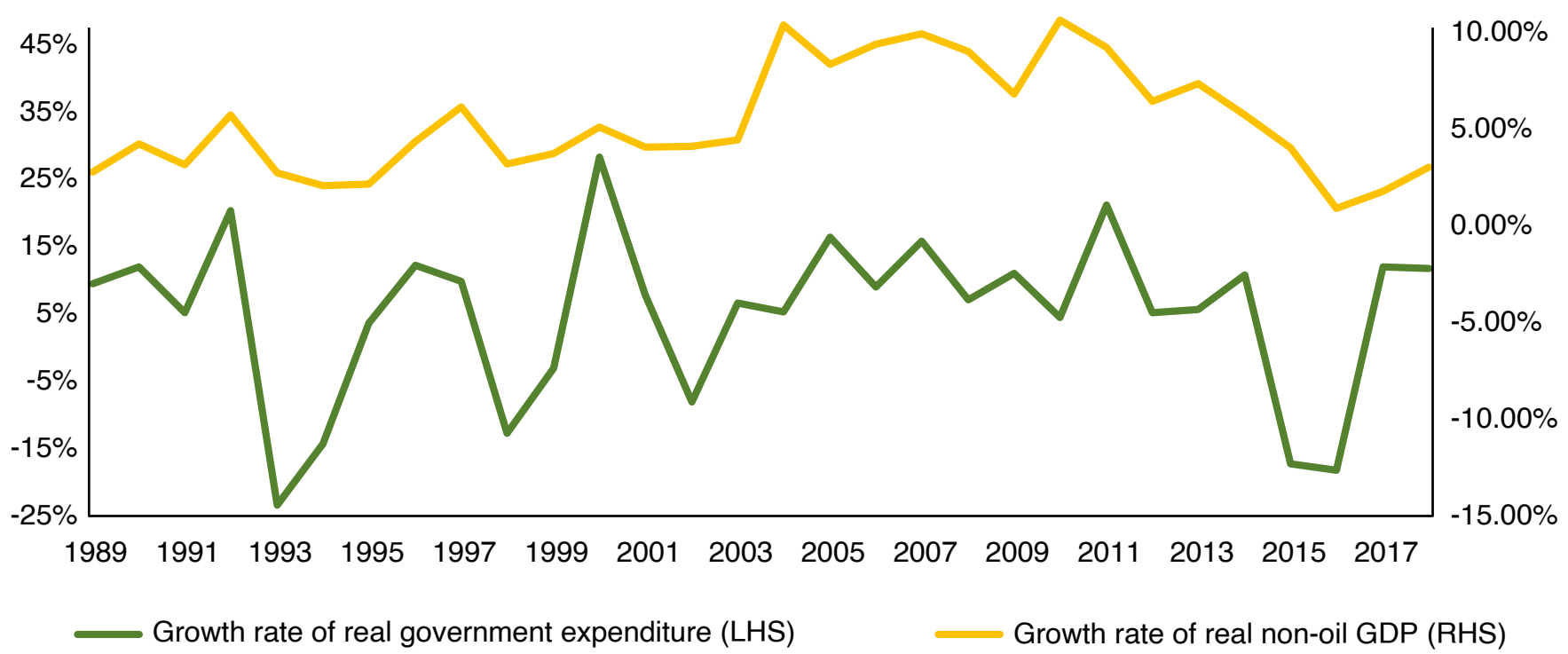

Source: Authors' calculation based on Ministry of Finance (MoF) and GaStat data via the Saudi Arabian Monetary Authority (SAMA) (2019). 
The last oil boom (2003-2014) allowed the government to increase its expenditure massively. According to figures from the Ministry of Finance via the Saudi Arabian Monetary Authority (SAMA) (2019), total government expenditure increased more than fourfold, from 257 billion Saudi riyals (SAR) in 2003 to 1,141 billion SAR in 2014. To meet the welfare demand of the growing population, the government also increased its expenditure on health and social development more than fourfold during this period. Massive investments in new infrastructure projects and improving existing projects were made to increase the efficiency and productivity of businesses in the country. As a result, from 2003-2014, the Kingdom experienced a strong annual economic growth of $5 \%$ on average. Non-oil GDP grew at a much higher rate than overall GDP $(7.2 \%$ on average), stimulated by increased government expenditure (Figure 2).

The decline in oil revenues caused the government to run fiscal deficits from 2014 and use other sources of financing. These included drawing down from its deposits and reserves at SAMA, issuing domestic and international government bonds, raising non-oil revenues and implementing economic reforms (e.g., subsidy reforms) to help achieve fiscal consolidation. Non-oil GDP growth slowed considerably during the oil price decline, probably due to the reduction in government expenditure, as Figure 1 illustrates.

Saudi Vision 2030 aims to decouple the economy from its dependence on oil through the implementation of several economic and social initiatives. The key economic goals announced in 2016 include increasing the private sector's contribution to GDP from $40 \%$ to $65 \%$, raising the share of non-oil exports in non-oil GDP from $16 \%$ to $50 \%$, and reducing the unemployment rate from $11.6 \%$ to $7 \%$ by 2030 . In its National Transformation Program 2020 (NTP), Saudi Arabia seeks to maximize local content to the tune of over $\$ 70$ billion, which will help to reduce the unemployment rate to $9 \%$ over the medium term.

Figure 2. Historical government expenditure for Saudi Arabia.

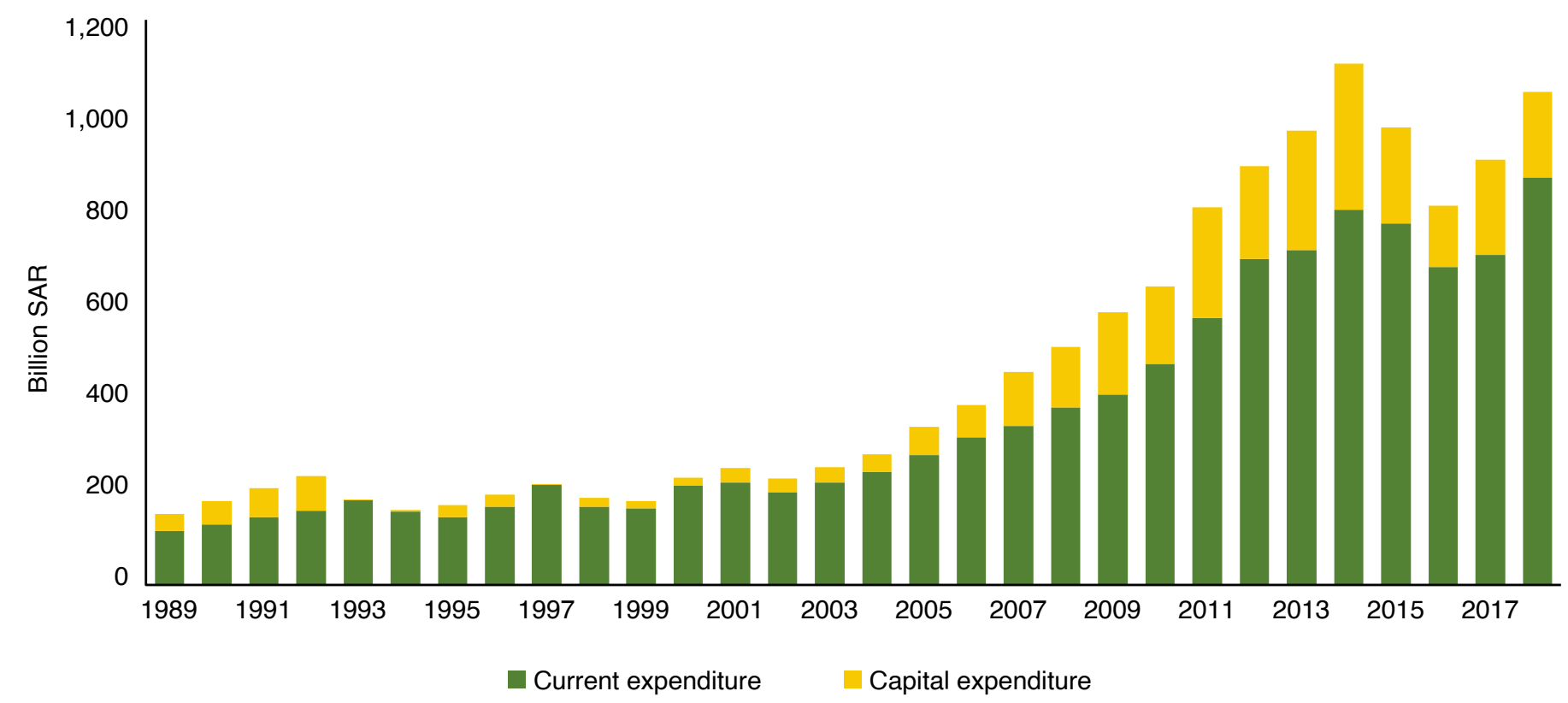

Source: MoF data via SAMA (2019). 
One can implicitly see the importance of two things, among others, in achieving the above-mentioned goals. First, developing the Kingdom's non-oil sector would help it meet these targets. Fiscal policy could also play a major role, given that Saudi monetary policy originated from the fixed exchange rate regime (pegging the SAR to the United States dollar).

Since the introduction of Vision 2030 in 2016 and its related Fiscal Balance Program (FBP), the government has implemented more concrete measures to diversify the government's revenues by increasing its non-oil revenues and targeting fiscal sustainability over the medium and long term. These measures have included the introduction of a value-added tax (VAT) for the first time in January
2018, excise taxes on tobacco, soda, energy and sweetened drinks, the introduction of expatriate levies, and increases in government service fees. These measures were complemented by energy price reform (EPR). As a result, non-oil revenues increased by a factor of three from 2015-2018. However, in 2018 , oil revenues remained at $67 \%$ of total revenues.

The government implemented a set of initiatives to support citizens and the private sector during the country's economic transformation. These initiatives included the introduction of the Citizen Account Program, maintenance allowances, a private sector stimulus plan, and other subsidies and social benefits aimed at helping the country adjust to the fiscal reforms. 


\section{Literature Review}

Whis section surveys the fiscal studies on the Saudi economy. Appendix A provides a detailed review of the existing Saudi fiscal studies and reports on their main limitations that this research will address.

Some general observations from this survey are:

Almost all studies in Table A1 used total expenditure, or its capital and current components, and found that fiscal policy positively impacted the country's economic growth. However, it is theoretically acknowledged that the former can have both a positive and negative effect on the latter.

Some studies used disaggregated components of government expenditure, and sometimes found a negative impact on economic growth.
Few studies provided theoretical foundations and appropriately addressed the stochastic properties of the time series data used (see the remark section of Table A1).

Some studies considered economic growth as a function of fiscal variable(s) only by ignoring its other determinants, such as capital and labor (see the remark section of Table A1).

The majority of the studies appropriately considered non-oil GDP instead of total GDP. 


\section{Theoretical Framework of the Study}

ome earlier studies have used a bivariate framework in which output is a function of only government expenditure (i.e., Al-Faris 2002; Al-Jarrah 2005). However, several theoretical and empirical studies argue that a bivariate framework can lead to misleading results. Moreover, both the magnitude and sign of the estimated coefficients can differ after introducing a third variable (Caporale and Pittis 1997; Caporale et al. 2004; Odhiambo 2008, 2009). It was also found that omitting relevant variables, as may be the case in a bivariable framework, may result in false Granger-causality results (Lutkepohl 1982; Triacca 1998). Therefore, we have not considered a framework in which economic growth is only the function of fiscal variable(s), unlike some studies have done, as documented in Table A1.

Thus, to appropriately explore the effect of fiscal policy on non-oil growth in Saudi Arabia, we consider a theoretically-grounded multivariable framework. To this end, we use the extended production function framework, following seminal theoretical and empirical studies such as Feder (1982), Ram (1986), Grossman (1988), Hansson and Henrekson (1994), Lin (1994), Ramey and Shapiro (1998), Alexiou (2009) as well as those for Saudi Arabia (Alshahrani and Alsadiq 2014; Eid and Awad 2017). The framework can be written as follows:

$$
Y=f(K, L, G C U, G C A)
$$

Here, $Y$ represents non-oil GDP, while $K$ and $L$ represent non-oil capital stock and non-oil employment, respectively. GCU and GCA represent the government's current and capital expenditure, respectively.

Note that the production function-based framework for analyzing economic growth effects of the government spending was developed in the 1980s by the seminal studies mentioned above, including Ram (1986). It was then augmented with various government current and capital spending components by Grossman (1988), Sala-i-Martin (1992), Hansson and Henrekson (1994), and Ramey and Shapiro (1998). Kneller et al. (1998) provided a comprehensive survey of empirical and theoretical studies that investigate the impacts of various components of government current and capital spending on economic growth.

Equation (1) can be re-expressed in the following form to be estimated econometrically:

$y_{t}=\alpha+\beta k_{t}+\gamma l_{t}+\lambda g c u_{t}+\mu g c a_{t}+\varepsilon_{t}$

Here, all the variables in equation (2) are expressed in lowercase to indicate that they are used at the logarithmic level. The elasticities of non-oil GDP with respect to $K, L, G C U$, and $G C A$ are represented by $\beta, \gamma, \lambda$, and $\mu$, respectively. The production function theory articulates that $\beta>0$ and $\gamma>0$, and the latter elasticity usually should be larger than the former elasticity (e.g., see Cobb and Douglas 1928; Douglas 1976; Senhadji 2000; Arezki and Cherif 2010). As for the signs of $\lambda$ and $\mu$, the theoretical studies discussed above are inconclusive, while the empirical fiscal studies for Saudi Arabia surveyed in the literature review section have generally found positive signs for the elasticities, particularly for the former elasticity. Government capital spending can affect economic development in the long run via channels such as investing in economic and social infrastructure, education, research and development, health, defense and security services. The long-run economic development effects of the government's current spending are felt mainly through the channels and determinants of economic development, including, but not limited to, private savings, human capital, fertility and inequality (see e.g., Aghion and Bolton 1997; Alesina and Rodrik 1994; Ehrlich and Kim 2005; 


\section{Theoretical Framework of the Study}

Glomm and Kaganovich 2008; Keane and Prasad 2002; Modigliani 1988; Persson and Tabellini 1994; Zhang 1995). Depending on which channels are at work, different theoretical and empirical results can be obtained for both capital and current spending (see comprehensive discussions in Kneller et al. 1998; Awaworyi and Yew 2017). For example, Barro (1989, 1991), Perotti (1996), Bellettini and Ceroni (2000), Zhang and Zhang (2004), and Lee and Chang (2006), among others, found that government transfers, an item of government current spending, positively affect economic growth. Whereas Awaworyi and Yew (2017), Ehrlich and Kim (2005), Ehrlich and Zhong (1998), Hansson and Henrekson (1994), among others, concluded that they negatively affect economic growth. However, Landau (1986), among others, did not find that government transfers significantly impacted economic growth. 


\section{Data}

W

e conduct this study using annual data for Saudi Arabia from 1989-2018. ${ }^{2}$ The following indicators are considered in the empirical analysis:

Non-oil value added $(Y)$, the dependent variable, is defined as the gross domestic product (GDP) excluding the mining and quarrying sector and net taxes. The data is collected from the General Authority for Statistics (GaStat) (2018) in million SAR at 2010 prices. For simplicity, we refer to this variable as non-oil GDP throughout the paper.

Current expenditure (GCU) represents government wages and salaries, transfers, and other government spending on public goods and services for current use. The data (in million SAR) is sourced from the Ministry of Finance (MoF) via the SAMA's Annual Statistics bulletin (SAMA 2019). The nominal values were deflated by the non-oil GDP deflator to get real values. The non-oil GDP deflator is calculated from the data from GaStat via SAMA (2019).

Capital expenditure (GCA) is defined as government spending on infrastructure and investment in physical assets such as health, defense, housing, transportations, among other sectors. The data was also obtained from the MoF via SAMA (2019) in million SAR. The nominal values were deflated by the non-oil GDP deflators to get real values.

Non-oil employment $(L)$ represents the total number of people employed, excluding those in the mining and quarrying sector. The data is sourced from GaStat via the CEIC's database and measured in thousand people (CIEC 2018).

Non-oil capital stock $(K)$ data is in million SAR at 2010 prices. It is constructed using the perpetual inventory method as expressed below (Collins, Bosworth and Rodrik 1996; Nehru and Dhareshwar 1993; Hall and Jones 1999; Caselli 2005):

$$
K_{t}=(1-\delta) K_{t-1}+I_{t}
$$

Where $K_{t}$ represents non-oil capital stock at time $t$, $\delta$ is the depreciation rate, and $I_{t}$ is the investment at time $t$. In the construction, we take non-oil investment in million SAR at 2010 prices from the Ministry of Economy and Planning via Oxford Economics. We assume a 5\% depreciation rate and that the initial level of the capital stock is assumed to be 1.5 times non-oil GDP in 1989. Lastly, we exclude government capital expenditure in real terms (GCA) from the resulting series to avoid double accounting in the empirical analysis (Mahraddika 2019; Francois and Keinsley 2019; Herzer and Morrissey 2013).

The natural logarithmic profiles and growth rates of the variables over the studied period are shown in Figure 3, below.

We notice that the profiles of all the indicators show an overall increase during the period under consideration. More specifically, non-oil GDP (Y) experienced a compound annual growth rate (CAGR) of $2.93 \%$ in 1989-2003, compared to $6.6 \%$ in 2004-2014. However, growth slowed from 2014-2016 due to falling oil prices but picked up again in 2017 and 2018. As we discussed government current and capital expenditures in the background section, we do not discuss them again here. Both GCU and GCA followed a similar pattern to $Y$ in having a steeper upward trend since 2003, low and even negative growth rates during 2014-2016, before recovering. Non-oil capital stock and labor also followed a similar pattern over the entire period, although their growth rates slowed during the oil price drop.

To conclude, overall, all the variables demonstrated similar patterns in their development trajectories, and this leads us to think that they can establish a relationship articulated by the economic theory. 
Figure 3. Time profiles of the variables.

Panel A: The logarithmic levels of the variables
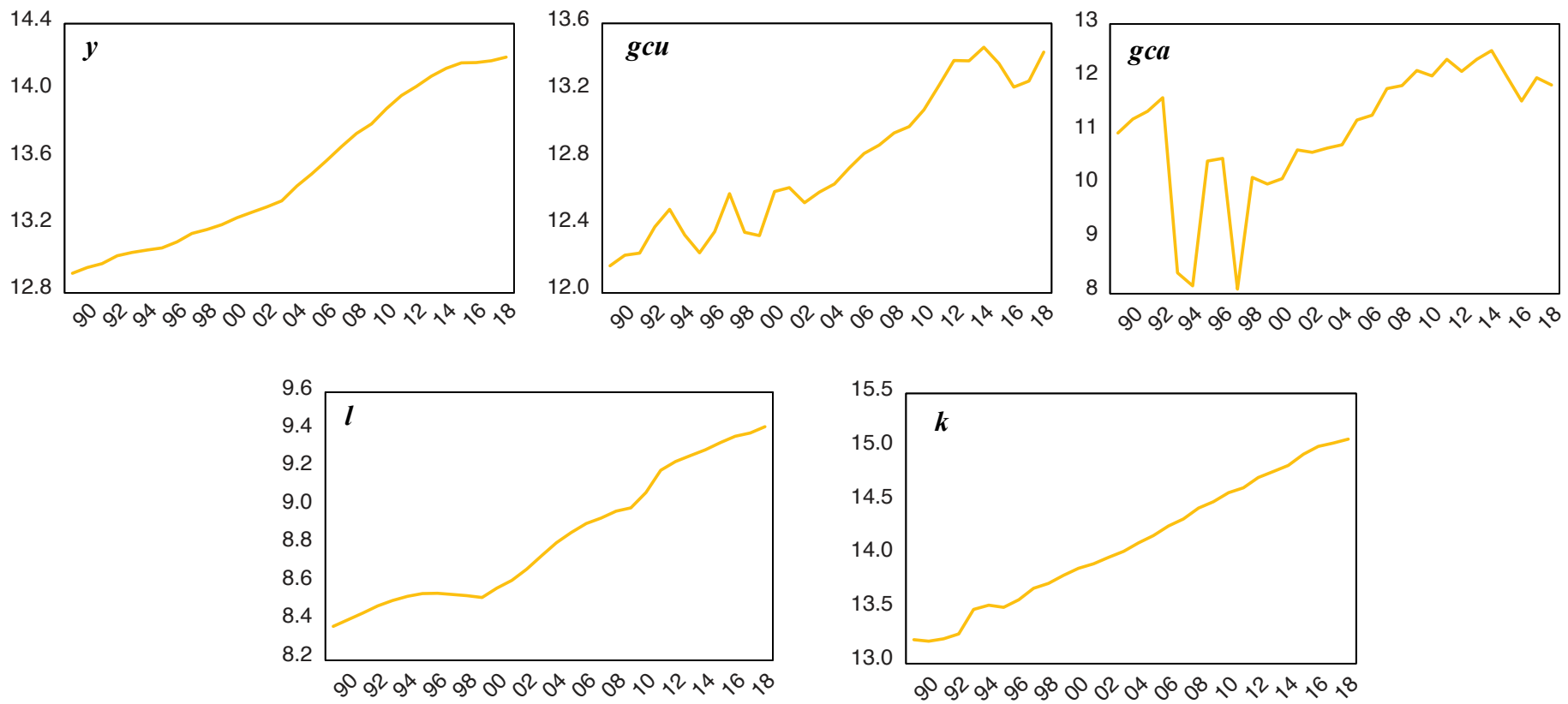

Panel B: The growth rates of the variables
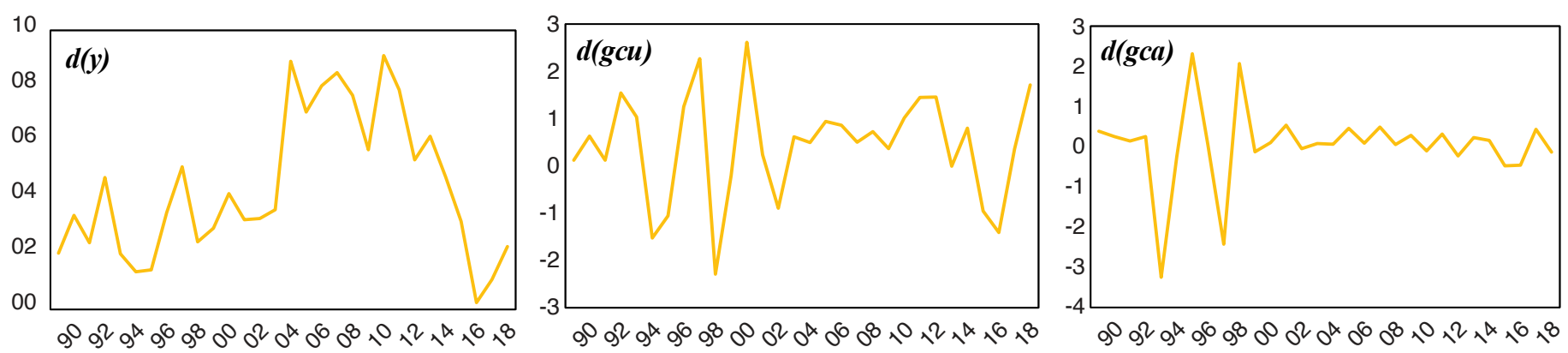

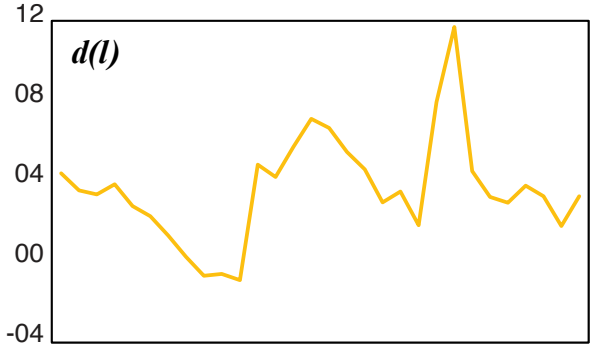

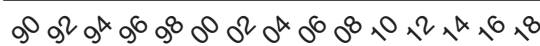

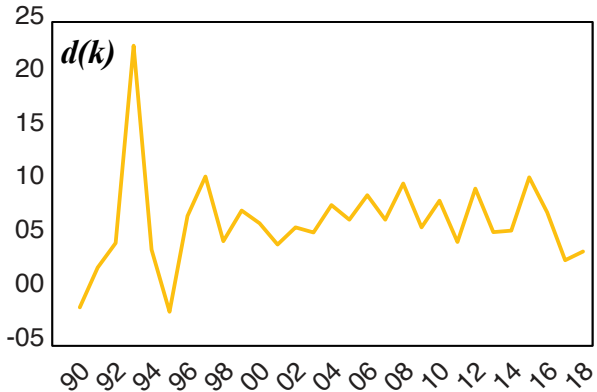

Source: Authors' own calculation. 


\section{Econometrics Methods}

his section discusses the econometric methods used in our research to estimate the impact of fiscal policy on Saudi Arabia's non-oil sector. Our empirical analysis starts by examining the stationarity properties of our variables using the augmented Dickey-Fuller (ADF) unit root test (Dickey and Fuller 1981). There are many tests aside from the ADF test that can be used to study the stationarity of series, but we prefer the Kwiatkowski-Phillips-Schmidt-Shin (KPSS) unit root test (Kwiatkowski et al. 1992), as it takes the null hypothesis of stationarity, unlike other conversational univariate unit root tests. Thus, we consider the KPSS test as a robustness check for the findings from the ADF test. As a further robustness check, we also apply unit root tests with structural breaks to our time series. If the variables have structural breaks in their development paths caused by economic expansion, recession, or extraordinary events such as war and natural diseases, conventional unit root tests such as the ADF or KPSS might produce misleading and uncommonly expected results. For example, a stationary variable, i.e., an I(0) with a break in its level, can be concluded as a non-stationary process. Or an integrated order of one, i.e., an I(1) variable with a break in its development trend, can be mis-concluded as an integrated order of two process, i.e., I(2) (see Perron 1989; Hansen 2001, among others). This is important as our sample period covers different development stages, such as expansions and recessions, that can cause structural breaks in the development paths of the variables. This can lead the ADF or KPSS tests to indicate the integration orders of the variables, which are not commonly expected, while we would expect all our variables to follow an I(1) process, with or without structural breaks, as a common-sense expectation. If this is the case, then we will perform a unit root test with a structural break and compare its findings with those from the ADF and/or KPSS.
It will help us to reach more robust conclusions about the integration orders of the variables. We will employ the ADF test with structural breaks (ADFBP) developed by Perron (1989), Perron and Vogelsang (1992a, 1992b), and Vogelsang and Perron (1998). The ADFBP has some advantages over other breakpoint tests because it can be applied regardless of whether (a) a break originated suddenly or smoothly, (b) it happened to trend, intercept, or both; (c) the break date is known or unknown. Details of both types of unit root tests can be found in the references mentioned above alongside Gujarati and Porter (2009), Enders (2015), and Dolado et al. (1990), Banerjee et al. (1992), Perron (2006), and Zivot and Andrews (1992).

If the series were found to be integrated of the same order, we would then employ the Johansen cointegration test (Johansen 1995) as the next stage of our analysis. Cointegration tests are employed to investigate the existence of long-run relationships between our variables. The Johansen test should be used as it can reveal a number of cointegrating relations if more than one regressor is involved in the analysis. Other cointegration methods cannot do that, and assuming a single co-integration relationship between the variables might lead to inaccurate estimations and, thus, incorrect conclusions. Additionally, small sample bias adjustment will be applied to the Johansen test statistics, i.e., trace and maximum-eigenvalue, as the Johansen cointegration method is designed for a larger sample size. We will adjust the sample values of the trace and maximum-eigenvalue statistics using the correction method developed by Reinsel and Anh (1992) and Reimers (1992). In the case of only one cointegrating relationship between the variables, we will use the autoregressive distributed lag (ARDL) method (Pesaran and Shin 1999) as the main method to estimate the long-run coefficients, given the small sample size. We will also use fully 


\section{Econometrics Methods}

modified ordinary least squares (FMOLS), dynamic ordinary least squares (DOLS) and canonical cointegreating regression (CCR) to enhance the robustness of our long-run estimations.

According to the Engle-Granger representation theorem, if variables estiablish a long-run relationship, then there is also an error correction representation of this relation (Engle and Granger 1987). Following this guidance, once the coefficients of the long-run relationship for non-oil GDP are estimated, then the residual of this relationship can be constructed. One lagged level of the constructed series, residuals, is an error correction term (ECT) and it is used to build an error correction model (ECM). An ECM is used to investigate the short-run relationship between the growth of non-oil GDP and the explanatory variables (see Enders 2015, among others).

We use the general-to-specific approach to estimate an ECM. The approach first estimates the general ECM with the maximum lag length of the variables, the contemporaneous values of the explanatory variables and the ECT. This is called a general unrestricted ECM. Once it is estimated, we try to get a specific, i.e., a parsimonious ECM, by excluding economically meaningless and statistically insignificant regressors while testing for residual diagnostics and misspecification. A discussion of the approach and its application to an ECM can be found in Campos et al. (2005), among others. 


\section{Empirical Analysis}

\subsection{Unit root test}

Following our research strategy, outlined in the previous section, we start our empirical analysis by testing the stochastic properties of the variables. For this purpose, we run the unit root tests, the results of which are reported in Table 1.

Table 1. Unit root test results.

\begin{tabular}{|c|c|c|c|c|c|c|c|c|c|}
\hline \multirow[t]{2}{*}{ Variable } & \multicolumn{5}{|c|}{ ADF Test } & \multicolumn{4}{|c|}{ KPSS Test } \\
\hline & Test value & $C$ & $t$ & None & $\boldsymbol{k}$ & Test value & $C$ & $t$ & None \\
\hline$y$ & -1.94 & & $x$ & & 1 & $0.15^{* *}$ & & $x$ & \\
\hline$g c u$ & -2.67 & & $x$ & & 0 & $0.13^{*}$ & & $x$ & \\
\hline$g c a$ & -3.30 & & $x$ & & 0 & 0.11 & & $x$ & \\
\hline$l$ & -1.95 & & $x$ & & 1 & 0.16 ** & & $x$ & \\
\hline$k$ & $-4.38^{* * *}$ & & $x$ & & 0 & $0.15^{* *}$ & & $x$ & \\
\hline$d(y)$ & -2.24 & $x$ & & & 0 & 0.21 & $x$ & & \\
\hline$d(g c u)$ & $-6.65^{* * *}$ & $x$ & & & 1 & 0.50 ** & $x$ & & \\
\hline$d(g c a)$ & $-7.38^{* * *}$ & & & $x$ & 1 & 0.22 & $x$ & & \\
\hline$d(l)$ & -2.72 * & $x$ & & & 0 & 0.19 & $x$ & & \\
\hline$d(k)$ & $-7.73^{\star * \star}$ & $x$ & & & 2 & 0.27 & $x$ & & \\
\hline
\end{tabular}

Notes: $d$ is the first difference operator. The maximum lag order is set to two, and the optimal lag order $(\boldsymbol{k})$ is selected based on the Schwarz criterion in the ADF test. ${ }^{* * *}$, ${ }^{* *}$ and * indicate rejection of the null hypotheses of having unit root in the ADF and stationarity (or trend stationarity) in the KPSS at the 1\%, 5\% and 10\% significance levels, respectively. The critical values for the ADF and KPSS tests are taken from MacKinnon (1996) and Kwiatkowski et al. (1992), respectively. The estimation period is 1989-2018. $\boldsymbol{C}, \boldsymbol{t}$ and None mean options of intercept, intercept and trend, and no intercept and no trend, respectively. $x$ indicates that the corresponding option is selected in the final unit root test equation.

According to the KPSS test statistics, $y$ is a unit root process at the $5 \%$ significance level, and the first difference of it, $d(y)$, is a stationary process, meaning that the integration order of the variable is one, that is an I(1) process. The ADF test result also indicates that $y$ is a unit root, i.e., a non-stationary process. However, it also shows that $d(y)$ is still a unit root process. Considering $y$ as a second order integrated process, I(2) is not consistent with the common finding of the empirical studies for the variable and the results of the KPSS test here. Moreover, Juselius (2006) discusses that for a given variable, an I(2) process can only be found over a very long time period and should not be used if the sample size is between 10-30 years. As discussed in the data section, $y$ has a noticeable break in its 


\section{Empirical Analysis}

development trend from 2004, translating to a level shift in $d(y)$, i.e., growth rates, as Panel B of Figure 3 illustrates. We suspect that the counterintuitive result from the ADF test on the integration order of $d(y)$ might be caused by that shift. Hence, we perform the ADFBP test, as discussed in the methodology section. ${ }^{3}$ We find the sample statistic of -5.32 , which is higher than the critical $1 \%$ significance level of -4.90 in absolute terms, meaning that the $d(y)$ is stationary with the level shift. Thus, the conclusion about $y$ is that it is an I(1) process.

According to the ADF test results, both expenditure variables, $g c u$ and $g c a$, are unit root processes, and the first differences of them, $d(g c u)$ and $d(g c a)$, are stationary. Since the graphical illustrations of the variables in panels $A$ and $B$ of Figure 3 , and the KPSS test results, support the findings of the ADF test, our conclusion about the budget variables is that they are I(1) processes. ${ }^{4}$

Both the ADF and KPSS test statistics in the table support the conclusion that $I$ is an I(1) process. The ADF suggests that $k$ is a trend-stationary process at the $1 \%$ significance level. In contrast, the KPSS test statistic shows that the variable is not a trend-stationary process at the $5 \%$ significance level. Both the tests show that the first difference of the variable, $d(k)$ is stationary. The graphical illustrations of the level of the variable in Panel $A$ of Figure 3 do not provide a clear picture as to whether it is a trend-stationary or difference-stationary process, as they show some swings in the beginning and at the end of the period, but a deterministically trending pattern inbetween. Thus, we will consider both conclusions in our short-run modeling.

Our conclusion from the unit root exercise is that all the variables are non-stationary at their levels, but the first differences of them are stationary.

\subsection{Long-run analysis}

We conduct the Johansen cointegration analysis following Juselius (2006). The main purpose of conducting the Johansen cointegration analysis is to discover a number of cointegrating relationships, since our analysis involves more than one explanatory variable. Table 2 documents the results of the residual diagnostics and stability tests for the estimated vector autoregression (VAR). It also presents the results of the cointegration tests.

As panels $A$ through $D$ tabulate, the residuals of the estimated VAR successfully pass serial correlation, normality and heteroscedasticity tests, and it satisfies the stability condition. All these features make the estimated VAR valid for the cointegration test. We test the existence of a long-run relationship in all five possible cases and find that the variables can be cointegrated in the cases of (a) and (b), as Panel $E$ shows. It is reasonable to think that (a) is less likely to be the case for the production function, both theoretically and empirically. Theoretically, skipping the intercept term means that we ignore total factor productivity, which is the part of the production function. Empirically, a number of studies find that total factor productivity plays a certain role in the Saudi production process (IMF 2013; Mitra et al. 2015; Alkhareif et al. 2017; Mousa 2018; Hasanov et al. 2019). Hence, we opt for case (b). To make a robust inference, we apply the small sample bias correction, suggested by Reinsel and Anh (1992) and Reimers (1992), to the sample values of the Trace and Max-Eigenvalue test statistics. Panel F shows that there is strong evidence of only one long-run relationship according to the values of the corrected tests. The conclusion of one long-run relationship is also in line with the theory of production (Douglas 1976; Cobb and Douglas 1928). Lastly, the test statistics in Panel $G$ indicate that labor and capital are not 
weakly exogenous to the long-run relationship established among the variables, which implies that the endogeneity issue of these variables should be taken into consideration in the ECM analysis of non-oil GDP growth.

Table 2. VAR residual diagnostics and cointegration test results.

Panel A: Serial correlation LM test ${ }^{\text {a }}$

\begin{tabular}{l|l|l|l|l|}
\hline Lags & LM-statistic & $\boldsymbol{p}$-value & Data trend: & None \\
\hline 1 & 30.22 & 0.22 & Test Type: & (a) No $\boldsymbol{C} \boldsymbol{t} t$ \\
\hline 2 & 28.45 & 0.29 & Trace: & 2 \\
\hline 3 & 25.62 & 0.43 & Max-Eig: & 1 \\
\hline
\end{tabular}

Panel B: Normality test ${ }^{b}$

\begin{tabular}{|c|c|c|c|c|c|c|c|c|c|}
\hline & \multicolumn{5}{|c|}{ type (b) } \\
\hline Statistic & $\chi^{2}$ & d.f. & p-value & $\begin{array}{l}\text { Null } \\
\text { hypothesis: }\end{array}$ & $r=0$ & $r \leq 1$ & $r \leq 2$ & & \\
\hline Skewness & 11.98 & 5 & 0.04 & $\lambda$ trace & $139.89^{\star \star \star}$ & $54.74^{\star \star}$ & 27.61 & & \\
\hline Kurtosis & 5.20 & 5 & 0.39 & $\lambda$ trace $^{a}$ & $113.98^{\star \star \star}$ & 44.60 & 22.50 & & \\
\hline \multirow{2}{*}{$\begin{array}{l}\text { Jarque- } \\
\text { Bera }\end{array}$} & 17.18 & 10 & 0.07 & $\lambda \max$ & $85.15^{\star \star \star}$ & $27.14^{\star}$ & 18.86 & & \\
\hline & & & & $\lambda \max ^{a}$ & $69.38^{\star \star \star}$ & 22.11 & 15.37 & & \\
\hline \multicolumn{5}{|c|}{ Panel C: Heteroscedasticity test ${ }^{c}$} & \multicolumn{5}{|c|}{ Panel G: Weak exogeneity test results ${ }^{\text {e }}$} \\
\hline White & $\chi^{2}$ & d.f. & p-value & & $y$ & gcu & gca & $l$ & $\boldsymbol{k}$ \\
\hline Statistic & 195.5 & 195 & 0.48 & $\chi^{2}(1)$ & $41.12^{\star \star *}$ & 4.63 & 0.45 & $29.88^{\star \star \star}$ & $51.61^{* * *}$ \\
\hline
\end{tabular}

Panel D: Stability test ${ }^{d}$

\begin{tabular}{l|l}
\hline Modulus & Root \\
\hline 0.93 & 0.93 \\
\hline 0.75 & 0.75 \\
\hline 0.43 & $0.40-0.17 \mathrm{i}$ \\
\hline 0.43 & $0.40+0.17 \mathrm{i}$ \\
\hline 0.03 & -0.03 \\
\hline
\end{tabular}

Notes: Our endogenous variables are $y, g c u, g c a, k$, and $l$, and the exogenous variables are the deterministic variables of $\boldsymbol{C}, \boldsymbol{t}$ and the dummy variable taking unity in 1993, and zero otherwise, to capture outliers in $k$ and $g c a$ as they violate the normality of the VAR residuals. We set the maximum lag order to 3 based on the data-dependent rule and reduce it to 1 as the optimum lag order (as we have a small sample size). This is satisfactory to remove the serial correlation from the residuals of the VAR.

${ }^{a}$ The null hypothesis in the serial correlation LM test is that there is no serial correlation at lag order $h$ of the residuals. ${ }^{b}$ System normality tests with the null hypothesis of the residuals are multivariate normal. ${ }^{\circ}$ The White heteroscedasticity test takes the null hypothesis of no cross terms heteroscedasticity in the residuals. ${ }^{\mathrm{d}}$ The VAR stability test results show that no roots of polynomial

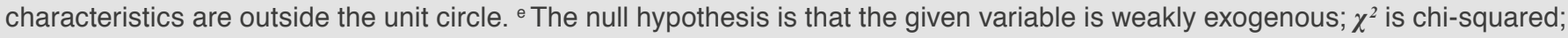
d.f. means degree of freedom; $\boldsymbol{C}$ and $\mathrm{t}$ indicate intercept and trend. $r$ is rank of $\Pi$ matrix, i.e., the number of cointegrated equations; $\lambda$ trace and $\lambda \max$ are the trace and max-eigenvalue statistics, while $\lambda$ trace a and $\lambda$ max a are the small sample bias correction versions of them using the method suggested by Reinsel and Anh (1992) and Reimers (1992). ${ }^{* * *}$ and * denote the rejection of the null hypothesis at the $1 \%$ and $10 \%$ significance levels, respectively. Critical values for the cointegration test are taken from MacKinnon et al. (1999). Estimation period: 1992-2018. 
We can now perform ARDL as we conclude that there is only one cointegrating relationship among the variables. ARDL is our main long-run estimation tool as it produces more robust results from small samples (Pesaran and Shin 1999; Pesaran et al.
2001). As a further robustness check, we also run FMOLS, dynamic ordinary least squares (DOLS), and CCR. Table 3 documents the results of the long-run estimation using the different methods.

Table 3. Long-run elasticities using ARDL, FMOLS, DOLS and CCR.

\begin{tabular}{l|l|l|l|l|l}
\multirow{3}{*}{ Methods } & $g c u$ & $g c a$ & $l$ & $k$ & $\boldsymbol{l}$ \\
\cline { 2 - 6 } & Coef. (P-value) & Coef. (P-value) & Coef. (P-value) & Coef. (P-value) & Coef. (P-value) \\
\hline ARDL & $0.21(0.00)$ & $0.02(0.00)$ & $0.56(0.00)$ & $0.25(0.00)$ & $2.07(0.00)$ \\
\hline FMOLS & $0.27(0.00)$ & $0.02(0.00)$ & $0.43(0.00)$ & $0.30(0.00)$ & $1.77(0.00)$ \\
\hline DOLS & $0.25(0.06)$ & $0.03(0.09)$ & $0.61(0.02)$ & $0.20(0.03)$ & $1.79(0.00)$ \\
\hline CCR & $0.28(0.00)$ & $0.02(0.02)$ & $0.42(0.00)$ & $0.30(0.00)$ & $1.72(0.00)$ \\
\hline
\end{tabular}

Notes: The dependent variable is $y ; c$ indicates the intercept term; coef= coefficient; estimation period: 1992-2018.

In the ARDL estimation, we set the maximum lag order to 3 based on the data-dependent rule, and the Schwarz information criterion selects $\operatorname{ARDL}(3,0,0,2,0)$ as the optimal specification. This specification passes all the diagnostics and misspecification tests. It also indicates a cointegrating relationship among the variables even after using Narayan (2005) critical values as a small sample bias correction. This supports the finding from the Johansen test. The results are available from the authors upon request.

Note that we included time trend in the long-run estimations above, but it appeared statistically insignificant in all the estimations. This is most likely because non-oil GDP and its explanatory variables share the common stochastic trend, i.e., they are cointegrated. Therefore, the stochastic trend in non-oil GDP is captured and canceled out by the stochastic trend in the explanatory variables; hence, there is no need for a deterministic trend in the estimations.

The estimated long-run elasticities of the explanatory variables obtained from the different methods have expected signs as the table shows. Additionally, their magnitudes are quite close to each other and they all appear statistically significant at the $5 \%$ and $1 \%$ significance levels. ${ }^{5}$ Based on the estimation results in the table, we can conclude that the long-run elasticities of non-oil GDP with respect to the government's current and capital expenditure average $\mathbf{0 . 2 5}$ and $\mathbf{0 . 0 2}$, respectively. Those for capital and labor average $\mathbf{0 . 2 6}$ and $\mathbf{0 . 5 1}$, respectively. We think that the narrow range of the estimated coefficients of the different methods is a merit of the estimations. Another merit is that the magnitudes of capital and labor are theoretically expected, i.e., the latter is greater than the former.

ARDL estimation-based coefficients are preferable for policy analysis and forecasting as they outperform their counterparts in small samples (Pesaran and Shin 1999). However, as Table 3 shows, the different methods yield similar coefficient magnitudes.

For further robustness, we also estimated the impacts of government current and capital expenditure, and non-oil capital and labor using the ratio of the fiscal indicators to non-oil GDP. This was the methodology used by Francois and Keinsley (2019), following the theoretical discussions in 
Landau $(1983,1985,1986)$ and the empirical discussion in Al-Yousif (2000) for Saudi Arabia. We used the same methods (i.e., VECM, ARDL, FMOLS, DOLS and CCR) as above. The cointegration test and estimation results are the same as above, i.e., there is a long-run relationship among the variables and the same signs for the explanatory variables are obtained. Even the magnitudes of the coefficients from these estimations and those in Table 3 are quite close to each other. To conserve space, the results are not reported here but are available from the authors upon request.

\subsection{Short-run analysis}

We estimated an ECM for the growth rate of non-oil GDP, $d(y)$, using OLS. First, we specified a general unrestricted ECM using an ECT, two lag lengths of the dependent variable, contemporaneous, and two lag lengths of the growth rates of the explanatory variables. ${ }^{6}$ The ECT was constructed using the long-run results from the ARDL estimation as follows:

$E C T_{t}=y_{t-1}-\left(2.07+0.21 * g c u_{t-1}+\right.$ $\left.0.02 * g c a_{t-1}+0.56 * l_{t-1}+0.25 * k_{t-1}\right)$.

We also included a pulse dummy variable, DP2004, taking unity in 2004 and zero otherwise, to capture a big jump in the growth rate of non-oil GDP in the general unrestricted ECM. This is also suggested by the graph and unit root test results of $d(y)$. The final ECM specification resulting from the general-to-specific approach, estimated using OLS, contains the ECT, the second lag of the dependent variable, the contemporaneous growth rates values of labor, current and capital expenditures, as well as one lag of the labor growth rate and intercept. All the estimated coefficients are statistically significant, and post-estimation tests results do not indicate any stability and residual diagnostics issues. ${ }^{7}$ Recall that the weak exogeneity test results documented in Panel G of Table 2 indicate that $d(l)$ and $d(k)$ are not weakly exogenous to the long-run relationship. We do not have $d(k)$ in the final ECM, but we have $d(l)$. Hence, we estimate the final ECM specification using a two-stage OLS (TSLS), in which we estimate an auxiliary equation for $d(l)$ using instrumental variables together with the main equation to address a potential endogeneity issue. ${ }^{8}$ Table 4 reports the estimation and test results.

The $J$ statistic indicates that the over-identification caused by using nine instrumental variables is valid, while $J_{D I F}$ shows that $d(l)_{t}$ is not an endogenous variable anymore. The sample values of $\chi_{S C}^{2}, \chi_{H E T}^{2}, \chi_{A R C H}^{2}$ and $J B_{N}$ statistics fail to reject the null hypotheses of no serial correlation, no heteroscedasticity, no autoregressive conditional heteroscedastic $(\mathrm{ARCH})$ effect and normal distribution in the residuals. Finally, the sample value of the $F$ statistic from the Ramsey regression equation specification error test (RESET) shows that the final specified ECM does not have any functional form mis-specification issue. The estimated coefficients reported in Table 4 are economically meaningful and statistically significant. ${ }^{9}$ The coefficients of the growth rates of the government's current and capital expenditure, as well as the net effect of labor growth, are positive and statistically significant. The coefficient of the ECT is statistically significant and its magnitude is in the acceptable range of $(0 ;-2)$, once again confirming a stable cointegration relationship between the variables. Consequently, the estimated coefficients of the final ECM can be used for analysis and forecasting purposes. 
Table 4. Final ECM specification and test results.

Panel A: Estimated coefficients of the final ECM specification

\begin{tabular}{l|l|l|l|l|l|l|l}
\hline Regressor & $E C T_{t}$ & $d(y)_{t-2}$ & $d(g c u)_{t}$ & $d(g c a)_{t}$ & $d(l)_{t}$ & $d(l)_{(t-1)}$ & $c$ \\
\hline Coefficient & -0.55 & 0.69 & 0.13 & 0.01 & 0.46 & -0.43 & -0.01 \\
\hline p-value & 0.00 & 0.00 & 0.00 & 0.01 & 0.11 & 0.06 & 0.21 \\
\hline
\end{tabular}

Panel B: Residual diagnostics, misspecification, over-identification and endogeneity tests results

\begin{tabular}{l|l|l|l|l|l|l|l}
\hline Statistic & $\chi_{S C}^{2}$ & $\chi_{H E T}^{2}$ & $\chi_{A R C H}^{2}$ & $J B_{N}$ & $F_{F F}$ & $J$ & $J_{D I F}$ \\
\hline Sample value & 1.50 & 8.58 & 2.71 & 0.45 & 0.00 & 0.26 & 0.03 \\
\hline p-value & 0.47 & 0.20 & 0.10 & 0.80 & 0.99 & 0.88 & 0.86 \\
\hline
\end{tabular}

Notes: Dependent variable is $d(y) t ; \chi_{S C}^{2}, \chi_{H E T}^{2}$ and $\chi_{A R C H}^{2}$ denote chi-squared statistics to test the null hypotheses of no serial correlation, no heteroscedasticity and no autoregressive conditioned heteroscedasticity $(\mathrm{ARCH})$ in the residuals, respectively. $F_{F F}$ is the $F$ statistic of the Ramsey RESET test for the null hypothesis of no functional form mis-specification; $J B_{N}$ indicates the Jarque-Bera test for the null hypotheses of the normal distribution of the residuals; $J$ is the $\mathrm{J}$-statistic for testing whether the null hypothesis of over-identification is valid; $J_{D I F}$ is the difference in the J-statistics for testing the null hypothesis of exogeneity of a given variable (in our case this is $d(l)$ ). Estimation period: 1992-2018. 


\section{Structural Break Analysis}

ne of the objectives of this study is to explore whether there is a break in the relationship that non-oil GDP establishes with government expenditure and other determinants, due to the recent oil price decline. Testing for a structural break is particularly important because we use the estimated parameters to make policy suggestions. A structural break can create instability in our estimated parameters, which would result in misleading numerical policy suggestions. The importance of testing structural breaks is discussed in Hendry (2018), Castle and Hendry (2014), Castle et al. (2015), Perron (2006), Chow (1960) and Gujarati (1970), among others.

The following two graphs give further clarity to the motivation behind this objective.

Graph b illustrates that oil revenues as a share of total government revenues increased from $66 \%$ in 1989 to $92 \%$ in 2012. As discussed earlier, the government's fiscal policy is crucial in directing the country's economic activity, as in all oil-based economies. Moreover, the share of the government sector in non-oil GDP has averaged $40 \%$. This indicates how significantly falling oil prices can create issues in the real economy if the government does not take adequate measures to mitigate their effects. Graph a of Figure 4 shows how the government's capital and current expenditure has declined considerably since 2014, and how the trend in non-oil GDP has flattened significantly since 2015.

One might suspect that these factors could create a structural break in the relationship between non-oil GDP and the government's current and capital expenditure.

To test this, we conducted a structural break analysis in this section. To get robust results, we performed three kinds of break analyses. First, we re-estimated both long- and short-run specifications until the oil price drop, i.e., until 2012, to examine how significantly the respective elasticities of the non-oil GDP estimated from the restricted sample of 1992-2012 and from the full sample of 1992-2018 can deviate from each other..$^{10}$ This gave us insights as to whether there was a structural break in the established relationship by visually comparing the respective coefficients estimated from the two different samples to find out how stable or unstable they are. Second, we performed a formal structural break test. To get robust results, we ran two different structural break tests, a Chow breakpoint test $(\mathrm{CHB})$ and a Chow forecast test (CHF). For further robustness, we ran a CHF for a few years, given that sometimes a break can occur gradually.

Third, we employed a dummy variable approach to investigating the structural break, as suggested by Gujarati and Porter (2009). The advantage of this approach is that, instead of dividing the entire sample into sub samples, which is sometimes not possible, it uses a dummy variable for the sample in which a structural break is suspected.

To obtain robust results and get a wide information set, we performed re-estimations and formal structural break tests, not only for the long-run but also the short-run relationships that non-oil GDP establishes with the government expenditure components.

The re-estimation results for the long- and short-run relationships are documented in Table 5.

Table 5 shows that both long- and short-run equations, re-estimated for 1992-2012, successfully pass the post-estimation tests and that the re-estimated coefficients are economically meaningful and statistically significant. The corresponding coefficients in panels $A$ and $B$ of the table are quite close to those estimated for the full sample of 1992-2018 in tables 3 and 4, respectively. 


\section{Structural Break Analysis}

In particular, the long-run coefficients of $g c u$ and $g c a$ and the short-run coefficients of $d(\mathrm{gcu})$ and $d(g c a)$, our main interest variables, are very close to each other, respectively, in the full sample and the restricted sample estimations. Based on the above results, it can be concluded that there is no parameter instability and, thus, no structural break

Figure 4. Oil revenues and the price of Arab Light crude. in the relationship between the non-oil sector and the government expenditure components alongside non-oil capital and non-oil labor.

Table 6 reports the results of the formal structural break tests.
Graph a: Price of Arab Light crude, (US\$/barrel)

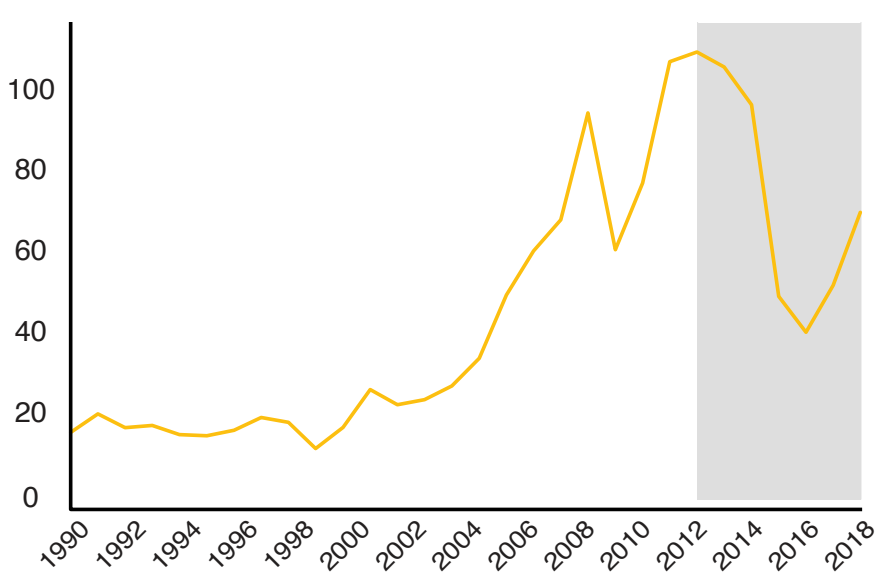

Source: SAMA (2019).

According to the sample values and associated probabilities reported in panels $A$ and $B$, the null hypothesis of no structural break cannot be rejected either in the Chow breakpoint or in the Chow forecast test. In other words, we do not find any evidence of a structural break in the long- or short-run relationship.

Finally, to run the structural break test suggested by Gujarati and Porter (2009), we created two dummy variables. They take unity for 2013-2018 and 2015-2018 and zero otherwise. The first dummy variable captures the oil price drop since 2013 (graph a, Figure 4), as in the previous two break exercises. The second dummy variable
Graph b: Oil revenue as a share of total revenue (\%)

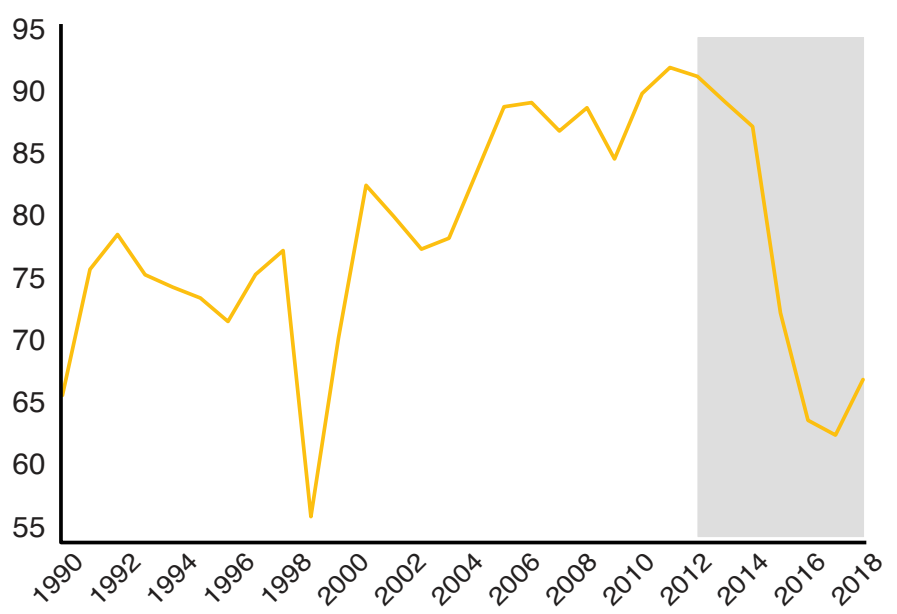

Source: Authors' calculation using MoF data via SAMA (2019).

captures the drop in the government's current and capital expenditure and the flattening of non-oil GDP since 2015 (Panel A, Figure 3). We included them in the ARDL specification that estimated the long-run relationship (see Table 3). The first and second dummy variables became statistically insignificant, with probability values of 0.14 and 0.28 , respectively. We did the same exercise for the final ECM specification estimated using a TSLS, which represents the short-run relationship between the growth rates of non-oil GDP and their respective variables (see Table 4). ${ }^{11}$ Again, the first and second dummy variables turned out to be statistically insignificant, with probability values of 0.70 and 0.84, respectively. As Gujarati and Porter (2009) 
discuss, a statistically insignificant dummy variable indicates that the null hypothesis of no structural break in a given period cannot be rejected. In other words, we could not find evidence of a structural break either in the long-run or in the short-run relationships of non-oil GDP.

Table 5. Re-estimation results for the long and short run.

\section{Panel A: Long run}

\begin{tabular}{l|l|l|l}
\hline \multicolumn{2}{l|}{ Re-estimation results for the ARDL } & Tests results & Sample value (P-value) \\
\hline Regressor & Coefficient (P-value) & Statistic & $0.90(0.44)$ \\
\hline$g c u$ & $0.22(0.00)$ & $F_{S C}$ & $0.70(0.41)$ \\
\hline$g c a$ & $0.02(0.01)$ & $F_{A R C H}$ & $0.72(0.66)$ \\
\hline$l$ & $0.78(0.00)$ & $F_{H E T}$ & $0.34(0.84)$ \\
\hline$k$ & $0.22(0.00)$ & $J B_{N}$ & $0.54(0.60)$ \\
\hline & $0.45(0.30)$ & $F_{F F}$ & $19.11 \mathrm{~A}^{*}$
\end{tabular}

Panel B: Short run

\begin{tabular}{l|l|l|l}
\hline \multicolumn{2}{l|}{ Re-estimation results for the final ECM } & Tests results & Sample value (P-value) \\
\hline Regressor & Coefficient (P-value) & Statistic & $0.61(0.73)$ \\
\hline$E C T_{t}$ & $-0.57(0.00)$ & $\chi_{S C}^{2}$ & $4.22(0.65)$ \\
\hline$d(y)_{(t-2)}$ & $0.66(0.00)$ & $\chi_{H E T}^{2}$ & $1.82(0.18)$ \\
\hline$d(g c u)_{t}$ & $0.12(0.01)$ & $\chi_{A R C H}^{2}$ & $1.16(0.56)$ \\
\hline$d(g c a)_{t}$ & $0.01(0.05)$ & $J B_{N}$ & $0.18(0.84)$ \\
\hline$d(l)_{t}$ & $0.61(0.05)$ & $F_{F F}$ & \\
\hline$d(l)_{(t-1)}$ & $-0.53(0.04)$ & & \\
\hline
\end{tabular}

Notes: Dependent long- and short-run variables are $y$ and $d(y)$, respectively.

$F_{S C}, F_{A R C H} F_{H E T}, F_{F F}$ and $F_{W}$ denote $F$ statistics to test the null hypotheses of no serial correlation, no autoregressive conditioned heteroscedasticity, no heteroscedasticity in the residuals, no functional form misspecification and no cointegration in the Wald test, respectively. $J B_{N}$ indicates the Jarque-Bera statistic to test the null hypotheses of the normal distribution of the residuals. In the ARDL estimation, the maximum lag order of two is selected based on the data-dependent rule; the Schwarz information criterion selected $\operatorname{ARDL}(1,0,0,2,0)$ as optimal.

A indicates that the sample statistic is greater than the upper bound of the critical value of Narayan (2005) at the $1 \%$ significance level in the given combination of the regressors and intercept included in the long-run equation.

* indicates that the sample statistic is greater than the upper bound of the critical value of Pesaran et al. (2001) at the 1\% significance level in the given combination of the regressors, the number of observations and the intercept included in the long-run equation.

$\chi_{S C}^{2} \chi_{H E T}^{2}$ and $\chi_{A R C H}^{2}$ denote chi-squared statistics to test the null hypotheses of no serial correlation, no heteroscedasticity and no autoregressive conditioned heteroscedasticity in the residuals, respectively.

The estimation sample is 1992-2012. 
Table 6. Structural break tests results.

\begin{tabular}{l|llllll} 
Break year & $\mathbf{2 0 1 3}$ & $\mathbf{2 0 1 3}$ & $\mathbf{2 0 1 4}$ & $\mathbf{2 0 1 5}$ & $\mathbf{2 0 1 6}$ & $\mathbf{2 0 1 7}$ \\
\hline Statistic & $\boldsymbol{F}_{C H B}$ & $\boldsymbol{F}_{C H F}$ & $\boldsymbol{F}_{C H F}$ & $\boldsymbol{F}_{C H F}$ & $\boldsymbol{F}_{C H F}$ & $\boldsymbol{F}_{C H F}$ \\
\hline \multicolumn{2}{l}{ Panel A: Test results for the long-run relationship } \\
Sample value & 0.16 & 0.51 & 0.60 & 0.78 & 0.98 & 1.40 \\
p-value & 0.86 & 0.79 & 0.70 & 0.55 & 0.42 & 0.27 \\
\hline Panel B: Test results for the short-run relationship & & & & 0.60 \\
Sample value & 0.37 & 0.29 & 0.35 & 0.44 & 0.62 & 0.42 \\
p-value & 0.70 & 0.93 & 0.87 & 0.78 & & \\
\hline
\end{tabular}

Notes: $F_{C H B}$ and $F_{C H F}$ denote the $F$ statistics of the Chow breakpoint test ( $C H B$ ) and the Chow forecast test ( $C H F$ ), respectively, to test the null hypotheses of no break in a given year. The varying regressors in the $C H B$ test in panels $\mathrm{A}$ and $\mathrm{B}$ are $g c u_{t}, g c a_{t}$ and $d(\mathrm{gcu})_{t}, d(\mathrm{gca})_{t}$, respectively. Note that the $C H B$ and $C H F$ tests cannot be applied to the ARDL estimation results, and they cannot be run for the TSLS estimations because of their small number of observations. Hence, we estimated the long-run relationship using OLS, and we used the OLS-based final ECM specification to apply the tests.

In summary, the results of all the different structural break estimations and tests applied above suggest that the oil price drop after 2012 did not create any structural breaks in either the long-run or short-run relationship that non-oil GDP establishes with the government's current and capital expenditure. 


\section{Discussion of the Empirical Findings}

$n$ this section, we discuss the findings of the unit root and cointegration tests before moving on to the long- and short-run parameter estimations and structural break analysis.

We decided that all our variables are non-stationary at their log levels and stationary at their growth rates, with and without structural breaks, based on the findings of the formal unit root tests (Table 1 and Figure 1). The implication of this non-stationarity is that any sudden changes and interventions to the (log) level of the variables may have permanent effects, and hence their mean variance and covariance change over time. Hence, it is difficult to predict the future values of the variables using their non-stationary transformations. The contrary, mean, variance and covariance of the variables' growth rates are quite stable over time, i.e., they are stationary. Any changes or interventions to the stationarity series have only temporary effects; thereby, the series reverts to its mean. These features of the stationary series make them attractive for use in forecasting.

The findings of the Johansen test, the main test, reported in Table 2, as well as those of the autoregressive distributed lag bounds tests (ARDLBT) in tables 3 and 5, to check for robustness, suggest that non-oil GDP establishes a cointegrating relationship with the government's current and capital expenditure as well as with non-oil capital and labor. Engle and Granger (1987) first discovered that although non-stationary series are to be used for analysis and forecasting with caution, because their mean, variance and covariance change over time, it is possible that such series share a common trend and thereby a linear combination of them produces a stationary process. If this is the case, then it is possible that the non-stationary variables establish a meaningful relationship that can be explained by economic theory. Such a relationship is called a cointegrating relationship; it is not spurious and can be used for analysis and forecasting.

Once a cointegrating (i.e., a long-run) relationship is found between the variables, it is meaningful and of use in estimating parameters, i.e., the numerical values of such a relationship. We first estimated the long-run elasticities of non-oil GDP with respect to the government's current and capital expenditure as our main variables, as well as with respect to non-oil labor and capital, as theoretically predicted determinants. To get robust results, we used the ARDL method as the main tool, as well as FMOLS, DOLS and CCR methods. It is a merit of this study that the estimated long-run elasticities from these three methods reported in Table 3 are quite close to one another. We then specified the ECM and estimated the short-run elasticities of non-oil GDP growth with respect to the growth rates of the government's current and capital expenditure, as well as non-oil labor and capital (Table 4).

Holding other factors constant, a $1 \%$ increase in the government's current and capital expenditure leads to increases of about $\mathbf{0 . 2 5} \%$ and $\mathbf{0 . 0 2} \%$, respectively, in the value added of the non-oil sector in the long run. The estimated short-run elasticities show that a $1 \%$ increase in the current and capital expenditure is associated with a $\mathbf{0 . 1 3 \%}$ and a $\mathbf{0 . 0 1 \%}$ increase, respectively, in non-oil GDP. Put differently, a 1 percentage point increase in the contemporaneous growth rates of current and capital spending results in 0.13 and a 0.01 percentage point increases in the growth rate of non-oil GDP.

It is worth recalling that elasticity and the slope coefficient (or multiplier) have different interpretations and implications. In this analysis, elasticity relates to percentage changes in 


\section{Discussion of the Empirical Findings}

non-oil GDP due to a $1 \%$ change in a given fiscal indicator. Whereas the multiplier measures a unit of monetary change in non-oil GDP caused by one unit of monetary change in a given fiscal indicator. The monetary equivalent of a $1 \%$ change can be significantly different from variable to variable. Because of this, policymakers may be interested in the multiplier effect rather than the elasticity effect, as the former gives the monetary change (SAR) in non-oil GDP for every additional 1 SAR spent by the government. It is therefore useful to also calculate multipliers here. The calculated long-run multipliers of non-oil GDP with respect to capital and current expenditure are 0.56 and 0.45 , respectively, while the short-run multipliers are 0.25 and 0.28 , respectively. ${ }^{12}$ The multipliers imply that a 10 SAR increase in capital and current spending leads to 5.6 SAR and 4.5 SAR increases, respectively, in non-oil GDP in the long run, while they increase non-oil GDP in the short run by 2.8 SAR and 1.8 SAR, respectively.

These findings deserve further discussion because the main objective of this research is to examine the non-oil growth effects of the government's current and capital expenditure.

Economic theory and empirical studies find both positive and negative growth effects of fiscal spending (see the discussion in Alesina et al. 2018, among others). However, our finding that fiscal spending positively effects growth in Saudi Arabia, confirming the Keynesian view and found in previous studies, can be explained accordingly. First, fiscal policy has a leading role in oil-based developing economies, including in the Saudi economy, driving economic activities (Looney 1986; 1989a, b; Al-Hamidy 2012; Hasanov et al. 2018; Sturm et al. 2009; Wakeman-Linn et al. 2002). Second, government expenditure is the primary way of injecting oil revenues into the economy, as the country's financial markets are not well developed, which is similar to the situation in many other developing countries (WB 1988; Looney 1989b; Al-Yousef 2000; Fasano and Wang 2001; Al-Hamidy 2012). Third, the oil sector is government owned, and oil revenues constitute a very large share of the the government's total revenues (from 1989-2018, it averaged $79 \%$ ). Government expenditure is the key channel for spillover from the oil sector to the non-oil sector (Fasano and Wang 2001; Al-Hamidy 2012). Fourth, the share of oil revenues transferred to the government's budget through total oil export revenues is very high (from 1989-2018, it averaged $78 \%$ ). This means that a large portion of government spending is facilitated by oil revenues, which in turn provides significant support to the country's non-oil economic growth.

We estimate the elasticity of current expenditure to be larger than that of capital expenditure in the long and short run. However, the long-run multiplier of capital expenditure is larger than that of current expenditure. Conversely, the short-run multiplier of current expenditure is larger than that of capital expenditure. These findings are in line with those of other multiplier studies for Saudi Arabia (e.g., see Tables 1 and 4 in Al Moneef and Hasanov 2020, which report existing available multipliers for Saudi Arabia). IMF (2016) assessed the long-run non-oil GDP multipliers of capital and current spending to be 0.8 and 0.5 , respectively, and the short-run multipliers as 0.2 and 0.3, respectively, for 1980-2015. IMF (2017) estimated the long-run non-oil GDP multipliers of capital and current expenditures to be 0.6 and 0.5, respectively, from 1990-2016. Al-Moneef and Hasanov (2020) estimated the non-oil private sector GDP multipliers of capital and current expenditures to be 0.47 and 0.32 , respectively, in the long run and 0.08 and 0.13 , respectively, in 
the short run for 1983-2018. As found in previous empirical studies, the multiplier impact of capital expenditure on GDP lasts longer than current expenditure, and thus becomes larger in the long run, whereas the opposite is true for the current expenditure.

The magnitudes of the capital spending multipliers are not too different from those of the current spending multipliers. This is not only true for the multiplier calculated in this study, but also for the findings of the IMF (2017) and AI Moneef and Hasanov (2020). The following explanations help to understand this finding.

We are not aware of any theoretical expectations for capital expenditure to have a larger positive effect than current spending. Some theoretical and empirical studies have even found negative growth effects of fiscal spending including capital expenditure (e.g., see the studies discussed in sections 3 and 4 ).

Earlier empirical studies found that capital expenditure has a weak positive effect on non-oil GDP in Saudi Arabia (Fasno and Wang 2001; Joharji and Starr 2010; Alshahrani and Alsadiq 2014; Mann and Sephton 2015; Eid and Awad 2017) and in GCC states (Espinoza and Senhadji 2011).

\section{Earlier empirical studies found that even} some components of capital spending may negatively impact non-oil GDP, because they are import-intensive rather than growth-efficient and crowd out private investment (Fasno and Wang 2001; Al-Faris 2002; Al-Jarrah 2005; Joharji and Starr 2010; Espinoza and Senhadji 2011; Alshahrani and Alsadiq 2014; Mann and Sephton 2015; Eid and Awad 2017).

Earlier studies have also found that current expenditure has a larger effect than capital expenditure on Saudi Arabian non-oil GDP (Joharji and Starr 2010; Alshahrani and Alsadiq 2014; Eid and Awad 2017).

The functioning of economies and the structure of fiscal spending are different across countries. Sturm et al. (2009), Al-Arbi et al. (2018), among others, find that current spending accounts for more than $80 \%$ of total government spending in GCC economies.

Moreover, the economic growth effects of fiscal spending depend, to a large extent, on its effectiveness and efficiency. In this regard, one of the findings of the previous studies is that there is a room for efficiency improvements at various stages of government spending, in particular capital expenditures in Saudi Arabia, as in other GCC and developing economies (Al-Faris 2002; Joharji and Starr 2010; Espinoza et al. 2013; Alshahrani and Alsadiq 2014; Eid and Awad 2017; Al-Arbi et al. 2018; IMF 2019).

Last but not least, a significant portion of capital goods and related services is imported, and this leakage reduces the magnitude of the impact of capital expenditure.

We also found positive effects of non-oil labor and capital on non-oil GDP in the long run. Holding other factors constant, a $1 \%$ increase in non-oil labor and non-oil capital increases non-oil GDP by, on average, $\mathbf{0 . 5 1} \%$ and $\mathbf{0 . 2 6} \%$, respectively, in the long run. In the short run, the net effect of non-oil labor

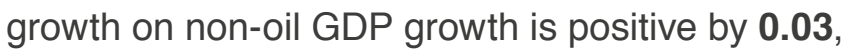
whereas non-oil capital growth does not exert any statistically significant impact from the estimations. The positive impact of labor and capital on output, with labor having greater elasticity than capital, is supported by the theories of production function and economic growth (Cobb and Douglas 1928; 


\section{Discussion of the Empirical Findings}

Douglas 1976; Solow 1956, 1957; Swan 1956) and empirical studies on Saudi Arabia. Hasanov et al. (2019) recently estimated the respective elasticities of labor and capital for the total economy as 0.6 and 0.2, respectively, for 1989-2015. In contrast, Aljebrin (2013) estimated labor and capital elasticities as 0.57 and 0.67 , respectively, for the total economy for 1984-2011.

\section{According to Engle and Granger (1987), if the} variables establish a long-run relationship, then deviations from this relationship in the short run are temporary and will eventually revert to the long-run relationship. Statistically, this is represented by the speed of adjustment (SoA) coefficient, which should be in the range of $(0 ;-2)$ and statistically significant. We estimated the SoA as -0.55 (Table 4). This indicates that if non-oil GDP deviates from the long-run relationship that it establishes with the government's current and capital expenditure, and non-oil labor and non-oil capital, due to policy interventions or domestic and foreign market factors in the present year, then $55 \%$ of this deviation will be corrected in the following year. This finding implies that non-oil GDP is strongly tied to government expenditure, non-oil labor and non-oil capital.
Indeed, earlier studies and the statistical results discussed above show that government expenditure is one of the main drivers of non-oil economic development in Saudi Arabia.

Lastly, we investigated whether there has been a structural break in the long-run and short-run relationships that non-oil GDP establishes with government expenditure, labor, and capital that could be caused by the persistent drop in international oil prices since 2012. We found that neither restricted sample estimations nor the formal structural break tests produced any evidence to support this. Among other factors, this suggests that Saudi Arabia's fiscal policy is growth-supportive in the period that included the oil price drop, as it was in the pre-oil price drop period. It also means that authorities in Saudi Arabia were able to successfully maintain the positive growth effects of fiscal spending. This is acknowledged in the International Monetary Fund's (IMF's) recent report on the Kingdom (see IMF 2019). 


\section{Conclusion and Policy Insights}

he purpose of this study was to explore the impact of Saudi Arabian fiscal policy on non-oil economic growth. While studying the effects of current and capital expenditure, we find that both have statistically significant positive impacts on non-oil GDP in the long and short run. In addition, the study finds no structural break in either the long- or short-run relationships. Therefore, several policy insights could be considered to maximize the effectiveness of government fiscal policy and support non-oil sector development. This would help to achieve the economic and social objectives of Saudi 2030.

First, the finding that non-oil capital and non-oil labor have large positive impacts on non-oil GDP in the long run implies that government expenditure could have a larger positive impact if it is directed toward projects that foster non-oil private investment and job creation. The government could consider focusing on developing human capital, including investing in education, vocational training and capacity building. Indeed, one of the Vision 2030 realization programs is dedicated to the development of human capital. Enhancing the investment environment for the private sector would increase its role in boosting non-oil economic growth. This would also help attain the objectives of Saudi Vision 2030 to diversify the country's economy.

Second, since 2017, the government has embarked on several public finance reforms to improve fiscal planning, public finance management, budget execution, and thus the efficiency of government expenditure. However, more reforms are needed to improve the efficiency of the government's expenditure, especially capital expenditure. To this end, the government has recently established the Center for Spending Efficiency.

Third, the government would be well advised to continue improving the Kingdom's business environment, and its economic, social infrastructure, and legislative frameworks. This would help to attract more domestic and foreign investment, among other positive externalities.

Fourth, the further involvement of the private sector in investment and job creation projects would support the development of the non-oil sector. Attracting more foreign direct investment would also enhance non-oil capital stock and help foster technological advancement. This would also help the country with its ongoing economic diversification.

Fifth, the government would be well advised to continue to reprioritize its spending to support the development of the non-oil economy in the short and long run. Increasing local content and reducing imported goods and services for final consumption and investments could help in this regard. Reducing the country's fiscal deficit, mainly by increasing non-oil revenues without hurting non-oil activities, would enhance the fiscal space. This would allow the government to increase its efficient expenditure while supporting fiscal sustainability over the long run, and it could be supported by the recently implemented medium-term macro-fiscal framework.

Some of the Kingdom's recent structural reforms are helpful in this regard, but more are needed. 


\section{Endnotes}

1. It is worth noting that this research does not aim to conduct a fiscal multiplier analysis, although we calculated multipliers for interested readers.

2. The start date of the data is dictated by the non-oil capital stock, which is calculated using the non-oil investment data. The analysis is therefore restricted to the availability of this data. The 2018 values for all the indicators are obtained from the MoF.

3. Note that we set the maximum lag at 2 and leave it for the Schwarz information criterion to select the optimum lag length. We consider the break as additive since it happens suddenly but not gradually.

4. Although the KPSS also has weak suggestions of trend-stationarity for cas and non-stationarity for $d(\mathrm{gcu})$, the graphical illustrations of the variables do not support these suggestions.

5. Only the elasticities of gcu and gca from the DOLS estimation are significant at the $5 \%$ and $10 \%$ significance level, respectively.

6. We included contemporaneous and two lag lengths of the de-trended capital stock variable in the unrestricted ECM as the unit test result suggested that the variable seemed to be trend-stationary. For robustness, we also specified another unrestricted ECM, in which we replaced the de-trended capital stock values with their growth rates. Note that both of these unrestricted ECMs led to the same final ECM specification, and changes in capital stock values, regardless of whether they were measured by de-trended or growth rates, did not survive in the final ECM specifications.

7. We do not report the final ECM specification estimated using OLS and its post-estimation tests results as this ECM is not the final one. However, the results are available from the authors upon request.

8. To save space, the discussion of the instrumental variables is available from the authors on request.

9. The coefficient of $d(l) t$ has the $11 \%$ significance level. We keep it in the final specification because of the following reasons: it has economically meaningful sign and size; exclusion of it causes the lagged value of $d(l) t$ being seriously insignificant. It also causes violation of homoscedasticity and weakening in the normality, non-serial correlation of the residuals as well as mis-specified functional form; given the number of observations we have it is not a big deal having $89 \%$ confidence interval.

10. It would also be an interesting exercise to re-estimate the long- and short-run specifications for the 2013-2018 sample, but six observation points prevent us doing so.

11. Since we included a shift dummy variable in the ARDL specification, which represents the level relationship, we included the first difference of this variable in the final ECM specification, which reflects the growth rates relationship (see Juselius 2006, among others, for a detailed discussion of using dummy variables in level and growth-rate relationships).

12. The multipliers are calculated here as the average values of respective estimated elasticities multiplied by the ratio of non-oil GDP to a given fiscal indicator, for the period 1992-2018. Details of the calculation are available from the authors upon request. Note that studies that have estimated/calculated multipliers have mainly focused on the endogeneity issue between the output and fiscal indicators. We are good in this regard, as Panel G in Table 2 indicates that both the fiscal indicators are weakly exogenous to non-oil GDP. 


\section{References}

Aghion, Philippe, and Patrick Bolton. 1997. "A Theory of Trickle-Down Growth and Development." The Review of Economic Studies 64 no. 2: 151-172.

Alesina, Alberto, and Dani Rodrik. 1994.

"Distributive politics and economic growth." The Quarterly Journal of Economics 109, no. 2: 465-490.

Al-Abri, Almukhtar, Ismail H. Genc, and George Naufal. 2018. "The Impact of Government Spending on GDP in a Remitting Country." IZA - Institute of Labor Economics, Discussion paper series, IZA DP No. 11676 .

Alesina, Alberto, Carlo A. Favero, and Francesco Giavazzi. 2018. "What do we know about the effects of austerity?" In AEA Papers and Proceedings, vol. 108, pp. 524-30.

Alexiou, Constantinos. 2009. "Government spending and economic growth: Econometric evidence from South Eastern Europe (SEE)." Journal of Economic and Social Research 11, no. 1: 1-16.

Al-Faris, Abdulrazak F. 2002. "Public expenditure and economic growth in the Gulf Cooperation Council countries." Applied Economics 34, no. 9: 1187-1193.

Al-Hamidy, Abdulrahman. 2012. "Aspects of fiscal/ debt management and monetary policy interaction: the recent experience of Saudi Arabia." BIS Paper $67 v$.

Aliyev, Khatai, and Ilkin Gasimov. 2018. "Fiscal policy implementation in Azerbaijan before, during and after the oil boom." Contemporary Economics 12, no. 1: 81-93.

Al-Jarrah, Mohammad A. 2005. "Defense spending and economic growth in an oil-rich country: The case of Saudi Arabia." Pakistan Economic and Social Review 43, no. 2: 151-166.
Al-Yousif, Yousif Khalifa. 2000. "Do government expenditures inhibit or promote economic growth: Some empirical evidence from Saudi Arabia." The Indian Economic Journal 48, no. 2: 92.

Aljebrin, Mohammed Abdullah. 2013. "A Production Function Explanation of Saudi Economic Growth 1984-2011." International Journal of Economics and Finance 5, no. 5: 97-103.

Alkhareif, Ryadh M., William A. Barnett, and Nayef Alsadoun. 2017. "Estimating the output gap for Saudi Arabia." SAMA Working Paper.

Al-Moneef, Majid, and Fakhri Hasanov. 2020. "The Fiscal Multipliers for Saudi Arabia Revisited." Forthcoming KAPSARC Discussion Paper.

Alshahrani, Saad. A., and Ali. J. Alsadiq. 2014. "Economic growth and government spending in Saudi Arabia: An empirical investigation." International Monetary Fund. IMF Working Paper No. WP/14/3.

Banerjee, Anindya, Robin L. Lumsdaine, and James H. Stock. 1992. "Recursive and sequential tests of the unit-root and trend-break hypotheses: theory and international evidence." Journal of Business and Economic Statistics 10, no. 3: 271-287.

Barro, Robert J. 1989. "Economic Growth in a Cross Section of Countries." Center for Economic Research (RCER), University of Rochester.

- - - 1991. "A cross-country study of growth, saving, and government." In National Saving and Economic Performance, edited by D. Bernheim and and J. Shoven. Chicago: The University of Chicago Press, pp. 269-304. 
Bellettini, Giorgio, and Carlotta Berti Ceroni. 2000. "Social security expenditure and economic growth: an empirical assessment." Research in Economics 54, no. 3: 249-275.

Berlemann, Michael, and Jan-Erik Wesselhöft. 2014 "Estimating aggregate capital stocks using the perpetual inventory method." Review of Economics 65 , no. 1: 1-34.

Campos, Julia, Neil R. Ericsson, and David F. Hendry. 2005. "General-to-specific modeling: An overview and selected bibliography." FRB International Finance Discussion Paper 838.

Callen, Tim, Reda Cherif, Fuad Hasanov, Amgad Hegazy and Padamja Khandelwal. 2014." Economic Diversification in the GCC: Past, Present, and Future." International Monetary Fund. Staff Discussion Notes No. 14/12.

Caporale, Guglielmo Maria, and Nikitas Pittis. 1997 "Causality and forecasting in incomplete systems." Journal of Forecasting 16, no. 6: 425-437.

Caporale, Guglielmo Maria, Peter G.A. Howells, and Alaa M. Soliman. 2004. "Stock market development and economic growth: the causal linkage." Journal of Economic Development 29, no. 1: 33-50.

Caselli, Francesco. 2005. "Accounting for cross-country income differences." Handbook of Economic Growth 1A: 679-741.

Castle, Jennifer L., and David F. Hendry. 2014. "Model selection in under-specified equations facing breaks." Journal of Econometrics 178: 286-293.

Castle, Jennifer, Jurgen Doornik, David Hendry, and Felix Pretis. 2015. "Detecting location shifts during model selection by step-indicator saturation." Econometrics 3, no. 2: 240-264.
Cherif, Reda, and Rabah Arezki. 2010.

"Development Accounting and the Rise of TFP." International Monetary Fund, Working Paper No. 10/101.

Chow, Gregory C. 1960. "Tests of equality between sets of coefficients in two linear regressions."

Econometrica 28, no. 3: 591-605.

Churchill, S. Awaworyi, and Siew Ling Yew. 2017. "Are government transfers harmful to economic growth? A meta-analysis." Economic Modelling 64: 270-287.

CIEC Database. 2018.

Cobb, Charles W., and Paul H. Douglas. 1928. "A theory of production." The American Economic Review 18(1): 139-165.

Collins, Susan M., Barry P. Bosworth, and Dani Rodrik. 1996. "Economic Growth in East Asia: Accumulation versus Assimilation." Brookings Papers on Economic Activity no. 2: 135-203.

Dickey, David A., and Wayne A. Fuller. 1981. "Likelihood ratio statistics for autoregressive time series with a unit root." Econometrica 49, no. 4: 1057-1072.

Dolado, Juan J., Tim Jenkinson, and Simon Sosvilla-Rivero. 1990. "Cointegration and unit roots." Journal of Economic Surveys 4, no. 3: 249-273.

Douglas, Paul H. 1976. "The Cobb-Douglas production function once again: its history, its testing, and some new empirical values." Journal of Political Economy 84, no. 5: 903-915. 
Ehrlich, Isaac, and Jinyoung Kim. 2005. "Social security, demographic trends, and economic growth: theory and evidence from the international experience." National Bureau of Economic Research Working Paper No. 11121.

Ehrlich, Isaac, and Jian-Guo Zhong. 1998. "Social security and the real economy: An inquiry into some neglected issues." The American Economic Review 88, no. 2: 151-157.

Eid, Ashraf Galal, and Ibrahim L. Awad. 2017. "Government Expenditure and Private Sector Growth in Saudi Arabia: A Markov Switching Model Analysis." Economic Issues 22, no. 2: 83-104.

El Mallakh, Ragaei. 2015. Saudi Arabia: Rush to Development (RLE Economy of Middle East): Profile of an energy economy and investment. Routledge.

Engle, Robert F., and Clive W.J. Granger. 1987. "Co-integration and error correction: representation, estimation, and testing." Econometrica J55, no. 2: 251-276.

Enders, Walter. 2015. Applied Econometric Time Series. John Wiley \& Sons.

Espinoza, Raphael A., Ghada Fayad, and Ananthakrishnan Prasad. 2013. The Macroeconomics of the Arab States of the Gulf. Oxford University Press. International Monetary Fund.

Espinoza, Raphael A., and Abdelhak Senhadji. 2011. "How strong are fiscal multipliers in the GCC? An empirical investigation." IMF Working Papers, No. $11 / 61$.
Fasano-Filho, Ugo, and Qing Wang. 2001. "Fiscal expenditure policy and non-oil economic growth: Evidence from GCC countries." International Monetary Fund, Working paper, No. 01/195.

Feder, Gershon. 1983. "On exports and economic growth." Journal of Development Economics 12, no. 1-2: 59-73.

Fisher, Franklin M. 1970. "Tests of equality between sets of coefficients in two linear regressions: An expository note." Econometrica 38, no. 2: 361-366.

Francois, John Nana, and Andrew Keinsley. 2019. "The long-run relationship between public consumption and output in developing countries: Evidence from panel data." Economics Letters 174: 96-99.

Frankel, Jeffrey A. 2011. "A solution to fiscal procyclicality: The structural budget institutions pioneered by Chile." No. w16945. National Bureau of Economic Research

General Authority for Statistics, Saudi Arabia (GaStat). 2018. National Accounts: Gross Domestic Product. https://www.stats.gov.sa/en/823

Glomm, Gerhard, and Michael Kaganovich. 2008. "Social security, public education and the growth-inequality relationship." European Economic Review 52, no. 6: 1009-1034.

Gujarati, Damodar N., and Dawn Porter. 2009. Basic Econometrics. McGraw-Hill International Edition.“

Gujarati, Damodar. 1970. "Use of dummy variables in testing for equality between sets of coefficients in two linear regressions: a note." The American Statistician 24, no. 1: 50-52. 
Grossman, Philip J. 1988. "Growth in government and economic growth: The Australian experience." Australian Economic Papers 27, no. 50: 33-43.

Hall, Robert E., and Charles I. Jones. 1999 "Why do some countries produce so much more output per worker than others?" The Quarterly Journal of Economics 114, no. 1: 83-116.

Hansen, Bruce E. 2001. "The new econometrics of structural change: dating breaks in U.S. labour productivity." Journal of Economic Perspectives 15, no. 4: 117-128.

Hansson, Pär, and Magnus Henrekson. 1994. "A new framework for testing the effect of government spending on growth and productivity." Public Choice 81, no. 3-4: 381-401.

Hasanov, Fakhri, Fuad Mammadov, and Nayef Al-Musehel. 2018. "The Effects of Fiscal Policy on Non-Oil Economic Growth.” Economies 6, no. 2: 27.

Hasanov, Fakhri J., Brantley Liddle, Jeyhun I. Mikayilov, and Carlo Andrea Bollino. 2019. "How Total Factor Productivity Drives Long-Run Energy Consumption in Saudi Arabia." In Energy and Environmental Strategies in the Era of Globalization edited by Muhammad Shahbaz and Daniel Balsalobre. Cham: Springer.

Hendry, David F. 2018. "Deciding between alternative approaches in macroeconomics." International Journal of Forecasting 34, no. 1: 119-135.

Herzer, Dierk, and Oliver Morrissey. 2013. "Foreign aid and domestic output in the long run." Review of World Economics 149, no. 4: 723-748.

International Monetary Fund (IMF). 2013. "Country report no 13/230, Saudi Arabia: Selected Issues."
- - 2016. "Country report, no. 16/32."

- - - 2017. "Country report, no 17/316, Saudi Arabia: 2017 Article IV Consultation-Press Release; and Staff Report."

- - - 2019. "Country report no 19/290, Saudi

Arabia: 2019 Article IV Consultation-Press Release; and Staff Report."

Johansen, Søren. 1995. Likelihood-based Inference in Cointegrated Vector Autoregressive Models.

Oxford University Press on Demand

Joharji, Ghazi A., and Martha A. Starr. 2010. "Fiscal policy and growth in Saudi Arabia." Review of Middle East Economics and Finance 6(3): 24-45.

Juselius, Katarina. 2006. The Cointegrated VAR Model: Methodology and Applications. Oxford University Press.

Keane, Michael P., and Eswar S. Prasad. 2002. "Inequality, transfers, and growth: New evidence from the economic transition in Poland." Review of Economics and Statistics 84, no. 2: 324-341.

Keynes, John Maynard. 1936. The General Theory of Employment, Interest and Money.

Kneller Richard, Michael F. Bleaney, and Norman Gemmell. 1998. "Growth, public policy and the government budget constraint: evidence from OECD countries." Discussion Paper no. 98/14, School of Economics, University of Nottingham.

Kwiatkowski, Denis, Peter C.B. Phillips, Peter Schmidt, and Yongcheol Shin. 1992. "Testing the null hypothesis of stationarity against the alternative of a unit root: How sure are we that economic time series have a unit root?" Journal of Econometrics 54, no. 1-3: 159-178. 
Landau, Daniel L. 1983. "Government Expenditure and Economic Growth: A Cross-Country Study." Southern Economic Journal 49, no. 3: 783-792.

- - . 1985. "Government expenditure and economic growth in the developed countries: 1952-76." Public Choice 47, no. 3: 459-477.

- - . 1986. "Government and economic growth in the less developed countries: an empirical study for 1960-1980." Economic Development and Cultural Change 35, no. 1: 35-75.

Lee, Chien-Chiang, and Chun-Ping Chang. 2006. "Social security expenditure and GDP in OECD countries: A cointegrated panel analysis." International Economic Journal 20, no. 3: 303-320.

Lin, Steven A.Y. 1994. "Government spending and economic growth." Applied Economics 26, no. 1: 83-94.

Looney, Robert E. 1986. "Socio-economic tradeoffs in Saudi Arabia's third five year plan (1980-1985)." Socio-Economic Planning Sciences 20, no. 4: 181-192.

-- - 1988. "Saudi Arabia's fiscal options: 1986-1992." Socio-Economic Planning Sciences 22, no. 3: 109-123.

---. 1989. Saudi Arabia's development strategy: comparative advantage vs. sustainable growth. Naval Postgraduate School, Monterey C.A.

- - . 1989. "The relative efficacy of monetary and fiscal policy in Saudi Arabia." Journal of International Development 1, no. 3: 356-372.

Lütkepohl, Helmut. 1982. "Non-causality due to omitted variables." Journal of Econometrics 19, no. 2-3: 367-378.
MacKinnon, James G., Alfred A. Haug, and Leo Michelis. 1999. "Numerical distribution functions of likelihood ratio tests for cointegration." Journal of Applied Econometrics 14, no. 5: 563-577.

Mahraddika, Wishnu. 2019. "Does international reserve accumulation crowd out domestic private investment?" International Economics 158: 39-50.

Mann, Janelle, and Peter Sephton. 2015. "Revising fiscal policy and growth in Saudi Arabia." Journal of Reviews on Global Economics 4: 139-146.

Mitra, Aniruddha, James T. Bang, and Arnab Biswas. 2015. "Gender equality and economic growth: Is it equality of opportunity or equality of outcomes?" Feminist Economics 21, no. 1: 110-135

Modigliani, Franco. 1988. "The role of intergenerational transfers and life cycle saving in the accumulation of wealth." Journal of Economic Perspectives 2, no. 2: 15-40.

Mousa, Mohamed. 2018. "The effect of cultural diversity challenges on organizational cynicism dimensions: A study from Egypt." Journal of Global Responsibility 9, no. 3: 280-300.

Narayan, Paresh Kumar. 2005. "The saving and investment nexus for China: evidence from cointegration tests." Applied Economics 37, no. 17:1979-1990

Nehru, Vikram, and Ashok Dhareshwar. 1993. "A new database on physical capital stock: sources, methodology and results." Revista de Análisis Económico 8, no. 1: 37-59.

Odhiambo, Nicholas M. 2008. "Financial depth, savings and economic growth in Kenya: A dynamic causal linkage." Econometric Modelling 25, no. 4: 704-713. 
---. 2009. "Electricity consumption and economic growth in South Africa: A trivariate causality test." Energy Economics 31, no. 5: 635-640.

Perotti, Roberto. 1996. "Growth, income distribution, and democracy: What the data say." Journal of Economic Growth 1, no. 2: 149-187.

Perron, Pierre. 2006. "Dealing with structural breaks." Palgrave Handbook of Econometrics vol. 1: 278-352.

---. 1989. "The great crash, the oil price shock, and the unit root hypothesis." Econometrica 57, no. 6: 1361-1401.

Perron, Pierre, and Timothy J. Vogelsang. 1992. "Testing for a unit root in a time series with a changing mean: corrections and extensions." Journal of Business \& Economic Statistics 10, no. 4: 467-470.

---. 1992. "Nonstationarity and level shifts with an application to purchasing power parity." Journal of Business \& Economic Statistics 10, no. 3 : 301-320.

Persson, Torsten, and Guido Tabellini. 1994. "Is Inequality Harmful for Growth." American Economic Review 84, no. 3: 600-621.

Pesaran, M. Hashem, Yongcheol Shin, and Richard J. Smith. 2001. "Bounds testing approaches to the analysis of level relationships." Journal of Applied Econometrics 16, no. 3: 289-326.

Pesaran, M. Hashem, and Yongcheol Shin. 1999. "An Autoregressive Distributed-Lag Modelling Approach to Cointegration." Chapter 11. In Econometrics and Economic Theory in the 20th Century: The Ragnar Frisch Centennial Symposium, edited by Steinar Strøm, 371-413. Econometric Society Monographs. Cambridge: Cambridge University Press.

Pieschacón, Anamaría. 2012. "The value of fiscal discipline for oil-exporting countries." Journal of Monetary Economics 59, no. 3: 250-268.

Ram, Rati. 1986. "Government size and economic growth: A new framework and some evidence from cross-section and time-series data." The American Economic Review 76, no. 1: 191-203.

Ramey, Valerie A., and Matthew D. Shapiro. 1998. "Costly capital reallocation and the effects of government spending." Carnegie-Rochester Conference Series on Public Policy 48: 145-194.

Reimers, H.E. 1992. "Comparisons of tests for multivariate cointegration." Statistical Papers 33, no. 1: 335-359.

Rubinson, Richard. 1977. "Dependence, government revenue, and economic growth, 1955-1970." Studies in Comparative International Development (SCID) 12, no. 2: 3-28.

Reinsel, Gregory C., and Sung K. Ahn. 1992. "Vector autoregressive models with unit roots and reduced rank structure: estimation, likelihood ratio test, and forecasting." Journal of Time Series Analysis 13, no. 4:353-375

Sala-i-Martin, Xavier. 1992. "Public Welfare and Growth." Yale University, Economic Growth Centre Discussion Paper No. 674.

Saudi Arabian Monetary Authority (SAMA). 2019. "Annual Statistics." May 31. 
Senhadji, Abdelhak. 2000. "Sources of Economic Growth: An Extensive Growth Accounting Exercise." IMF staff papers 47, no. 1: 129-157.

Solow, Robert M. 1956. "A contribution to the theory of economic growth." The Quarterly Journal of Economics 70, no. 1: 65-94.

- - - 1957. "Technical change and the aggregate production function." The Review of Economics and Statistics 39, no. 3: 312-320.

Sorsa, Piritta. 1999. "Algeria: The Real Exchange Rate, Export Diversification, and Trade Protection." International Monetary Fund, Working Paper No. 99/49

Sturm, Michael, François Gurtner, and Juan Gonzalez Alegre. 2009. "Fiscal Policy Challenges in Oil Exporting Countries: A Review of Key Issues." European Central Bank Occasional Paper Series 104.

Swan, Trevor W. 1956. "Economic growth and capital accumulation." Economic Record 32, no. 2: 334-361.

Triacca, Umberto. 1998. "Non-causality: The role of the omitted variables." Economics Letters 60, no. 3: 317-320.
Wakeman-Linn, John, Paul Mathieu, and Bert van Selm. 2002. "Oil funds and revenue management in transition economies: the cases of Azerbaijan and Kazakhstan: Fiscal Policy Formulation and Implementation in Oil-Producing Countries."

World Bank (WB). 1988. World Tables. Baltimore: John Hopkins University Press.

Vogelsang, Timothy J., and Pierre Perron. 1998. "Additional tests for a unit root allowing for a break in the trend function at an unknown time." International Economic Review 39, no. 4: 1073-1100.

Zhang, Jie. 1995. "Social security and endogenous growth." Journal of Public Economics 58, no. 2: 185-213.

Zhang, Jie, and Junsen Zhang. 2004. "How does social security affect economic growth? Evidence from cross-country data." Journal of Population Economics 17, no. 3: 473-500.

Zivot, Eric, and Donald W. K. Andrews. 1992. "Further evidence on the Great Crash, the oil-price shock, and the unit-root hypothesis." Journal of Business \& Economic Statistics 10, no. 3: 251-270. 


\section{A detailed review of time series studies on fiscal policy and economic growth relationship in Saudi Arabia}

The table below provides a comprehensive review of the fiscal studies on the fiscal and output measures used, the periods and methods considered, the numerical impacts estimated (slopes, elasticities and multipliers), and also some suggested areas of improvement for future research.

Table A1. A survey of the Saudi Arabian fiscal studies.

\begin{tabular}{|c|c|c|c|c|c|}
\hline Name & \begin{tabular}{|l} 
Fiscal \\
measure \\
used
\end{tabular} & \begin{tabular}{|l|} 
Output \\
measure \\
used
\end{tabular} & $\begin{array}{l}\text { Method and } \\
\text { period }\end{array}$ & Fiscal elasticity & Remarks \\
\hline $\begin{array}{l}\text { Ghali } \\
(1997)\end{array}$ & $\begin{array}{l}\text { SGE, } \\
\text { SGI, } \\
\text { SGC }\end{array}$ & $\begin{array}{l}\text { Growth of } \\
\text { GDP per } \\
\text { capita }\end{array}$ & $\begin{array}{l}\text { VAR, Granger- } \\
\text { Causality } \\
\text { analysis } \\
1960 \text { - } 1996\end{array}$ & \begin{tabular}{|l|} 
Neither elasticities \\
nor multipliers \\
were reported. \\
No consistent \\
evidence that \\
government \\
spending can \\
increase per \\
capita GDP \\
growth.
\end{tabular} & $\begin{array}{l}\text { - The conclusion from Table } 2 \text { is that the variables are } \\
\text { trend-stationary. It is well-known that trend-stationarity } \\
\text { is a type of non-stationarity, and de-trending should } \\
\text { be performed to make such variables stationary and } \\
\text { usable for short-run analyses (see Enders } 2015 \text {, among } \\
\text { others). However, such a remedy was not considered } \\
\text { when Grange causality was conducted, although the } \\
\text { study mentions that non-stationarity may cause spurious } \\
\text { results. } \\
\text { - We suspect that, due to the above-mentioned issue, } \\
\text { the study does not find statistically significant effects } \\
\text { of either the size of the government's expenditure, } \\
\text { investment or consumption on economic growth in Saudi } \\
\text { Arabia. It is hard to be convinced by these findings, } \\
\text { given that the Saudi economy, like any other developing } \\
\text { resource-rich country, is heavily reliant on the oil } \\
\text { revenues and thus fiscal spending. }\end{array}$ \\
\hline \begin{tabular}{l|} 
Mann \& \\
Sephton** \\
$(2015)$
\end{tabular} & $\begin{array}{l}\text { GCA, } \\
\text { GCU, } \\
\text { GDE, } \\
\text { GEE, } \\
\text { GHE, } \\
\text { GHUE }\end{array}$ & $\begin{array}{l}\text { Y per } \\
\text { capita }\end{array}$ & $\begin{array}{l}\text { VECM and } \\
\text { Impulse } \\
\text { response } \\
\text { analysis } \\
1971 \text { - } 2012\end{array}$ & $\begin{array}{l}\text { GCA: }-0.005(\mathrm{SR}) \\
\text { GCU: } 0.080(\mathrm{SR}) \\
\text { GDE: }-0.068(\mathrm{SR}) \\
\text { GEE: } 0.335(\mathrm{SR}) \\
\text { GHE: }-0.171(\mathrm{SR}) \\
\text { GHUE: } 0.022(\mathrm{SR})\end{array}$ & $\begin{array}{l}\text { - The study found four cointegrating, i.e., long-run, } \\
\text { relationships among the variables. However, none of } \\
\text { them were reported. } \\
\text { - If post-estimation test results were reported, then } \\
\text { readers could get information about Gaussian } \\
\text { conditions, stability and other issues of the VAR/VECM } \\
\text { that the study bases its findings on. }\end{array}$ \\
\hline 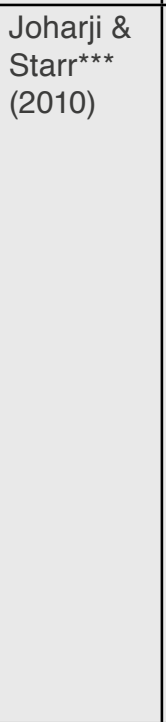 & $\begin{array}{l}\text { GE, } \\
\text { GCA, } \\
\text { GCU }\end{array}$ & $\mathrm{Y}$ & $\begin{array}{l}\text { VAR and } \\
\text { VECM } \\
1969-2005\end{array}$ & $\begin{array}{l}\text { GE: } 0.66 \text { (LR), } \\
-0.13 \text { (SR) } \\
\text { GCA: } 0.18 \text { (LR), } \\
-0.05 \text { (SR) } \\
\text { GCU: } 0.51 \text { (LR), } \\
-0.14(\mathrm{SR})\end{array}$ & $\begin{array}{l}\text { - It is hard to justify (a) that, theoretically, economic } \\
\text { growth is only the function of fiscal variables while } \\
\text { missing key drivers such as labor and capital, (b) having } \\
\text { both expenditures (LEX) and revenues (LR) in the } \\
\text { same equation of non-oil GDP (LY) as the explanatory } \\
\text { variables, since they are highly correlated and can } \\
\text { cause multicollinearity issues. We think this might be } \\
\text { why the study found the LR negative and insignificant in } \\
\text { the LY equation. } \\
\text { - The following findings in Figure } 1 \text { need explaining } \\
\text { becasue they seem unusual: } \\
\text { - Shocks to LR do not have any statistically significant } \\
\text { impact on LEX. } \\
\text { - Shocks to LY have statistically significant permanent } \\
\text { effects on LR. However, as the paper discusses, in } \\
\text { reality } 80 \% \text { of LR comes from oil revenues, not from } \\
\text { LY. } \\
\text { - The shock effects of LEX on LY never die out. }\end{array}$ \\
\hline
\end{tabular}




\begin{tabular}{|c|c|c|c|c|c|}
\hline $\begin{array}{l}\text { Al-Abri et al. } \\
(2018)\end{array}$ & GE growth & $\begin{array}{l}\text { Growth } \\
\text { of } Y\end{array}$ & \begin{tabular}{|l} 
Multiplier \\
analysis using \\
VAR \\
$1980-2015$
\end{tabular} & \begin{tabular}{|l|} 
The \\
estimated// \\
calculated \\
multipliers \\
are: \\
GE growth \\
without \\
remittances: \\
0.87 (SR) \\
GE growth \\
with \\
remittance: \\
0.90 (SR)
\end{tabular} & $\begin{array}{l}\text { - Investigating the relationship among the growth } \\
\text { rates of the variables ignores a possible long-run } \\
\text { relationship between them. } \\
\text { - Because a time series analysis is carried out, } \\
\text { illustrating the time profile of the variables used } \\
\text { would be very useful for readers' understanding. }\end{array}$ \\
\hline $\begin{array}{l}\text { Hemrit and } \\
\text { Benlagha*** } \\
\text { (2018) }\end{array}$ & $\begin{array}{l}\text { GAGE, } \\
\text { GHE, } \\
\text { GCONE, } \\
\text { GTE }\end{array}$ & $\begin{array}{l}\text { OAG, } \\
\text { OHE, } \\
\text { OCON, } \\
\text { OT }\end{array}$ & \begin{tabular}{|l} 
Multiplier \\
analysis using \\
VAR \\
1970 - 2015
\end{tabular} & 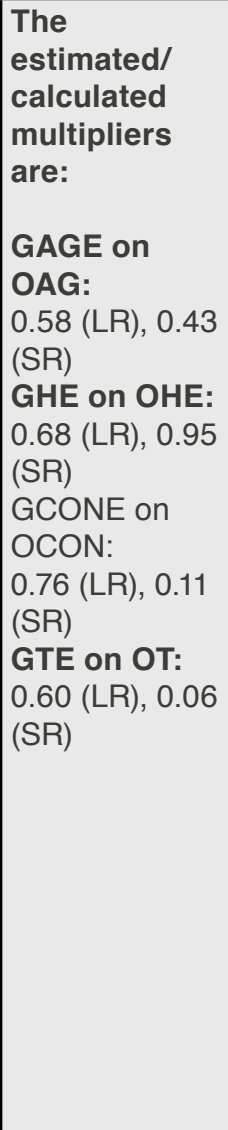 & $\begin{array}{l}\text { - Government expenditure is estimated as a function of } \\
\text { its two lags and one lag of private consumption and } \\
\text { gross fixed capital formation in Table } 4 \text {. It would be } \\
\text { useful to describe the theoretical foundation of this } \\
\text { specification. } \\
\text { - The following concerns about the conducted } \\
\text { Johansen test in Table } 5 \text { should be mentioned: } \\
\text { - Since a unit root test was not performed, it was } \\
\text { unknown whether the variables involved in the } \\
\text { cointegration analysis were I(1) or I(0) or I(2), which } \\
\text { would require different types of treatment before } \\
\text { running the cointegration analysis. } \\
\text { - If post-estimation test results were reported, } \\
\text { readers could get information about Gaussian } \\
\text { conditions, stability and other issues of the } \\
\text { VAR/VECM that the study used for impulse- } \\
\text { responses or to calculate multipliers. } \\
\text { - Estimated equations seem to be a-theoretical. } \\
\text { For example, value added in transportation and } \\
\text { communication is not only driven by government } \\
\text { spending. Other key drivers, such as capital and } \\
\text { labor, as economic theory articulates, are missed } \\
\text { here. It is well known that omitting theoretically } \\
\text { predicted variables can lead to misleading results. } \\
\text { Maybe that is the reason why the study failed to find } \\
\text { a cointegrating relationship between the sectoral } \\
\text { non-oil GDP and government expenditure in the } \\
\text { majority of cases. }\end{array}$ \\
\hline
\end{tabular}




\begin{tabular}{|c|c|c|c|c|c|}
\hline $\begin{array}{l}\text { Al-Faris } \\
\text { (2002) }\end{array}$ & $\begin{array}{l}\text { SGE, } \\
\text { GCA per } \\
\text { capita, } \\
\text { GCU per } \\
\text { capita }\end{array}$ & $\begin{array}{l}\text { GDP per } \\
\text { capita }\end{array}$ & $\begin{array}{l}\text { Johansen } \\
\text { Cointegration } \\
\text { Test, Granger } \\
\text { Causality Test } \\
1970-1997\end{array}$ & $\begin{array}{l}\text { Neither } \\
\text { elasticities nor } \\
\text { multipliers were } \\
\text { reported. } \\
\text { Wagner law } \\
\text { holds and } \\
\text { Keynesian } \\
\text { theory does not } \\
\text { hold. }\end{array}$ & 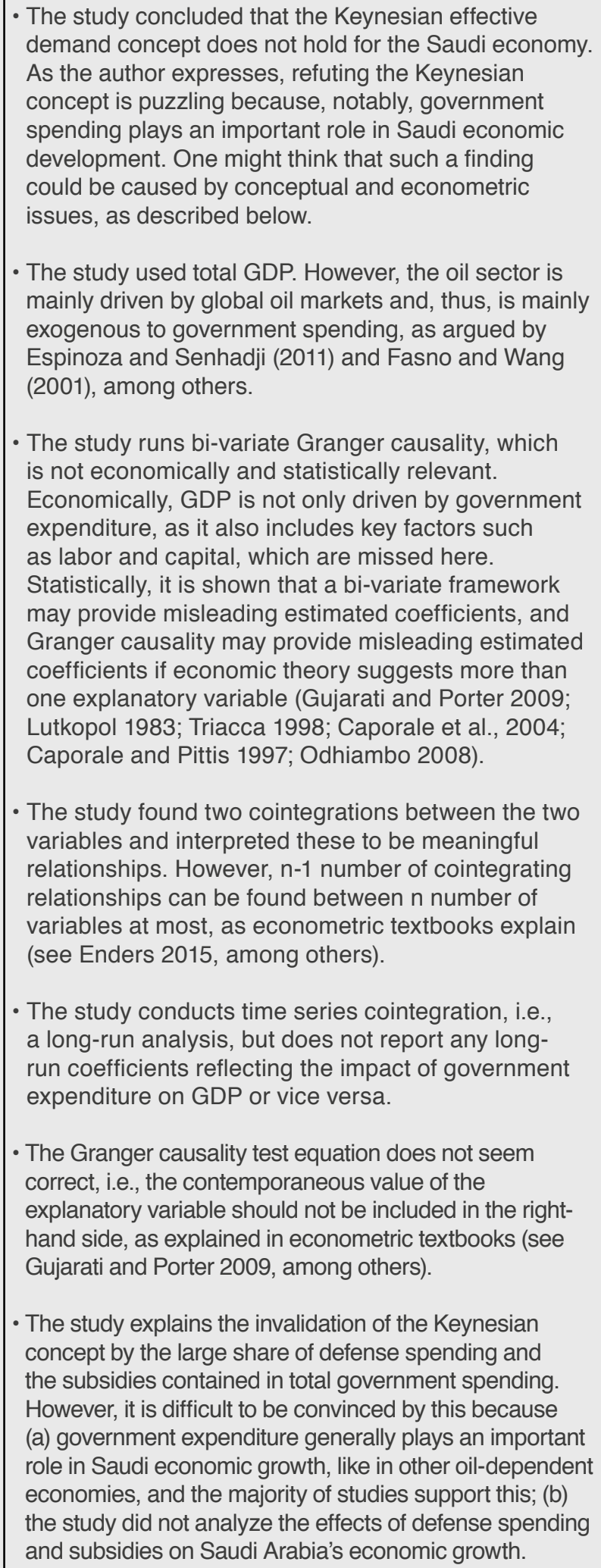 \\
\hline
\end{tabular}




\begin{tabular}{|c|c|c|c|c|c|}
\hline $\begin{array}{l}\text { AL-Jarrah } \\
\text { (2005) }\end{array}$ & $\begin{array}{l}\text { Government } \\
\text { defense } \\
\text { expenditure } \\
\text { ratio (GDER) }\end{array}$ & $\begin{array}{l}\text { GDP, } \\
Y\end{array}$ & $\begin{array}{l}\text { VECM and } \\
\text { Granger } \\
\text { Causality } \\
1968-2003\end{array}$ & $\begin{array}{l}\text { Neither } \\
\text { elasticities nor } \\
\text { multipliers were } \\
\text { reported. } \\
\text { The paper } \\
\text { concluded that: } \\
\text { GDER has } \\
\text { a negative } \\
\text { impact on real } \\
\text { GDP (LR). } \\
\text { Bi-directional } \\
\text { causality } \\
\text { between GDP } \\
\text { and GDER } \\
\text { (SR). } \\
\text { A uni- } \\
\text { directional } \\
\text { causality } \\
\text { running from Y } \\
\text { to GDER (SR). }\end{array}$ & $\begin{array}{l}\text { - The study was missing a theoretical framework, and } \\
\text { thus it was not clear which school(s) of thought it } \\
\text { followed. } \\
\text { - The study conducted a long-run analysis but did not } \\
\text { report long-run coefficients or elasticities. } \\
\text { - The study used a bi-variate framework, in which } \\
\text { GDP is only the function of defense spending and } \\
\text { vice versa. However, theoretically, there are major } \\
\text { determinants of GDP, such as capital and labor, } \\
\text { which are missed here. It is well known that such } \\
\text { a bi-variate framework can lead to spurious results } \\
\text { economically and statistically (Lutkepohl 1982; } \\
\text { Triacca 1998; Caporale et al. 2004; Caporale and } \\
\text { Pittis } 1997 ; \text { Odhiambo 2008). Therefore, the paper's } \\
\text { findings of cointegration and causality should be } \\
\text { considered with caution. } \\
\text { - The sample period of the study covers recessions } \\
\text { and expansions, which might cause structural } \\
\text { breaks in the data used. Hence, a unit root test } \\
\text { with a structural break should be considered. It is } \\
\text { well known that in the case of structural breaks, } \\
\text { conventional unit root tests (URTs) can produce } \\
\text { misleading results. Maybe that is why the study found } \\
\text { non-oil GDP as I(2), while common sense would } \\
\text { indicate that the variable follows an I(1) process. }\end{array}$ \\
\hline $\begin{array}{l}\text { Eid and } \\
\text { Awad } d^{\star \star \star} \\
(2017)\end{array}$ & $\begin{array}{l}\text { GC growth, } \\
\text { GCA growth, } \\
\text { GDE, } \\
\text { GEDE, } \\
\text { GHDE, } \\
\text { GHE }\end{array}$ & $\begin{array}{l}\text { Growth } \\
\text { of private } \\
\text { Y per } \\
\text { capita }\end{array}$ & $\begin{array}{l}\text { Markov } \\
\text { switching } \\
\text { autoregressive } \\
\text { model } \\
1970 \text { - } 2015\end{array}$ & $\begin{array}{l}\text { GC: } 0.048 \\
\text { (HS), }-0.25 \text { (LS) } \\
\text { GCA: }-0.007 \\
\text { (HS), }-0.09 \text { (LS) } \\
\text { GDE: }-0.06 \\
\text { (HS), }-0.03 \text { (LS) } \\
\text { GEDE: } 0.035 \\
\text { (HS), }-0.0007 \\
\text { (LS) } \\
\text { GHDE: } 0.069 \\
\text { (HS), } 0.042 \\
\text { (LS) } \\
\text { GHE: } 0.18 \\
\text { (HS), } 0.13 \text { (LS) }\end{array}$ & $\begin{array}{l}\text { - Investigating a relationship among the growth } \\
\text { rates of the variables ignores a possible long- } \\
\text { run relationship between them. This can cause } \\
\text { misleading results due to the so-called omitted } \\
\text { variable bias issue. } \\
\text { - An explanation of the negative effect of population, } \\
\text { as a measure of the labor force, on per capita non-oil } \\
\text { private GDP growth is needed since economic theory } \\
\text { articulates a positive relationship. } \\
\text { - It does not explain why non-oil private GDP growth is } \\
\text { expressed in per capita terms while other variables } \\
\text { are not. } \\
\text { - Table } 3 \text { reports that only the first lag out of four } \\
\text { lags of the dependent variable is statistically } \\
\text { significant. However, the study kept the lag order of } \\
\text { four, which is statistically insignificant and causes } \\
\text { over-parameterization. }\end{array}$ \\
\hline
\end{tabular}




\begin{tabular}{|c|c|c|c|c|c|}
\hline $\begin{array}{l}\text { Al-Yousef }{ }^{\star \star \star} \\
(2000)\end{array}$ & $\begin{array}{l}\text { GE growth, } \\
\text { SGE }\end{array}$ & \begin{tabular}{|l|} 
GDP \\
growth
\end{tabular} & $\begin{array}{l}\text { OLS } \\
1963-1992\end{array}$ & $\begin{array}{l}\text { GE growth: } \\
\text { [0.3:0.5] } \\
\text { SGE: }-0.703\end{array}$ & $\begin{array}{l}\text { - The study mentions that the estimation results do } \\
\text { not suffer from the spurious regression problem } \\
\text { since differenced forms of the variables were used. } \\
\text { However, the problem might still be evident, as the } \\
\text { study did not perform the unit root test. It is therefore } \\
\text { not known whether the differenced forms of the } \\
\text { variables were stationary. } \\
\text { - If the study used the stationary variables, then the } \\
\text { results could still be biased, as cointegration theory } \\
\text { articulates that if the variables are cointegrated and } \\
\text { it is not accounted for in the short-run analysis, then } \\
\text { the estimations are subject to the omitted variables } \\
\text { bias problem (Engle and Granger 1987). } \\
\text { - The study used total GDP. However, the oil sector } \\
\text { component is mainly driven by global oil markets and, } \\
\text { thus, is mainly exogenous to government spending, } \\
\text { as argued by Espinoza and Senhadji (2011) and } \\
\text { Fasno and Wang (2001), among others. } \\
\text { - It is hard to be convinced by the regression results, } \\
\text { as the R-squared value equals } 0.34 \text { in the best case, } \\
\text { meaning that the explanatory variables explain only } \\
34 \% \text { of the variation in the dependent variables. So, } \\
\text { the remaining } 66 \% \text {, which is a significant portion, } \\
\text { remains unexplained in the analysis. We think this is } \\
\text { partly because the study used total GDP. }\end{array}$ \\
\hline $\begin{array}{l}\text { Espinoza } \\
\text { and } \\
\text { Senhaji*** } \\
(2011)\end{array}$ & $\begin{array}{l}\text { GE growth, } \\
\text { GCA growth, } \\
\text { GCU growth }\end{array}$ & $\begin{array}{l}\text { Growth } \\
\text { of } Y\end{array}$ & $\begin{array}{l}\text { Multiplier } \\
\text { analysis using } \\
\text { VAR } \\
1975-2009\end{array}$ & $\begin{array}{l}\text { The estimated/ } \\
\text { calculated } \\
\text { multipliers are: } \\
\text { GE growth: } \\
0.5 \text { (LR), } 0.2 \\
\text { (SR) } \\
\text { GCA: } 1.0 \text { (LR), } \\
0.54 \text { (SR) } \\
\text { GCU: } 0.12 \text { (SR) }\end{array}$ & $\begin{array}{l}\text { - Investigating a relationship among the growth } \\
\text { rates of the variables ignores a possible long-run } \\
\text { relationship between them. } \\
\text { - Since a unit root test was not performed, it is difficult } \\
\text { to make a conclusion on the variables' time series } \\
\text { properties. For example, it is difficult to conclude that } \\
\text { non-oil GDP growth is an I(0) variable, as it trends } \\
\text { over time with a break in } 1986 \text { in Figure } 1 .\end{array}$ \\
\hline $\begin{array}{l}\text { Alshahrani } \\
\text { and } \\
\text { Alsadiq*** } \\
(2014)\end{array}$ & $\begin{array}{l}\text { GE, } \\
\text { GCA, } \\
\text { GCU, } \\
\text { GEE, } \\
\text { GHE, } \\
\text { GDE, } \\
\text { GHUE }\end{array}$ & $\begin{array}{l}\text { Y per } \\
\text { capita }\end{array}$ & $\begin{array}{l}\text { Cointegration, } \\
\text { OLS, } \\
\text { VAR, VECM } \\
1969 \text { - } 2010\end{array}$ & $\begin{array}{l}\text { GE: } 2.96 \text { (LR), } \\
-0.011 \text { (SR) } \\
\text { GCA: } 0.001 \\
\text { (SR) } \\
\text { GCU: } \\
-1.25(\text { LR), } \\
-0.012 \text { (SR) } \\
\text { GEE: } 0.093 \\
\text { (SR) } \\
\text { GHE: } 0.41 \\
\text { (LR), -0.026 } \\
\text { (SR) } \\
\text { GDE: }-0.37 \\
\text { (LR), }-0.02 \text { (SR) } \\
\text { GHUE: }-0.20 \\
\text { (LR), }-0.001 \\
\text { (SR) }\end{array}$ & $\begin{array}{l}- \text { In Table 2, the Johansen cointegration test results } \\
\text { indicated that models } 2,3,5 \text { and } 9 \text { had more than } \\
\text { one cointegrating relationship. However, the study } \\
\text { assumed only one cointegrating relationship among } \\
\text { the variables. Ignoring second or third cointegrating } \\
\text { relations can lead to an omitted variable bias in } \\
\text { the short run if their ECTs provide a statistically } \\
\text { significant impact for non-oil GDP per capita growth. }\end{array}$ \\
\hline Ageli (2013) & GEE & $\begin{array}{l}\text { GDP, } \\
\mathrm{Y}\end{array}$ & $\begin{array}{l}\text { OLS, } \\
\text { cointegration, } \\
\text { error correction } \\
\text { model (ECM) } \\
1970-2012\end{array}$ & $\begin{array}{l}\text { For GDP, } \\
\text { GEE: } 0.87 \\
\text { For Y, } \\
\text { GEE: } 0.92\end{array}$ & $\begin{array}{l}\text { - GDP and non-oil GDP is not only dependent } \\
\text { on government spending on education. Theory } \\
\text { articulates that output, such as capital and labor, } \\
\text { is the main determinant, which was missed here. } \\
\text { Omitting the theoretically predicted variables in the } \\
\text { analysis might result in biased results. }\end{array}$ \\
\hline
\end{tabular}




\begin{tabular}{|c|c|c|c|c|c|}
\hline $\begin{array}{l}\text { Fasno and } \\
\text { Wang } \\
\text { (2001) GCC }\end{array}$ & $\begin{array}{l}\text { GCA } \\
\text { GCU }\end{array}$ & \begin{tabular}{|l|} 
GDP, \\
$Y$
\end{tabular} & 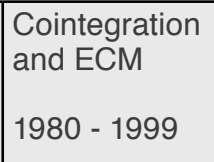 & \begin{tabular}{|l} 
GCA: 0.05 \\
(SR), $0.21(\mathrm{LR})$ \\
GCU: - 0.002 \\
(SR), 0.06 (LR)
\end{tabular} & $\begin{array}{l}\text { - The study has a second long-run relationship but } \\
\text { does not identify it. This may cause an omitted } \\
\text { variable bias issue, as discussed above. }\end{array}$ \\
\hline Eid (2015) & $\begin{array}{l}\text { SGC, } \\
\text { SCA }\end{array}$ & $\begin{array}{l}\text { Private } \\
\text { Y per } \\
\text { capita }\end{array}$ & $\begin{array}{l}\text { ARDL } \\
1969-2014\end{array}$ & $\begin{array}{l}\text { SGC: } 0.14(\text { LR), } \\
-0.14(\text { SR) } \\
\text { SCA: } 0.44 \\
(\text { LR), } 0.003 \\
(\text { SR) }\end{array}$ & $\begin{array}{l}\text { - It does not report why the long-run relationship was } \\
\text { not estimated/calculated from the ARDL estimation in } \\
\text { Table } 5 . \\
\text { - It seems from Table } 5 \text { that the study took into } \\
\text { consideration the impact of population on non-oil } \\
\text { private GDP twice, as population was included on } \\
\text { both sides of the estimated equation. } \\
\text { - Readers might want to see an explanation for why } \\
\text { insignificant dummy variables have been kept in } \\
\text { the estimation (Table } 5 \text { ) as they consumed two } \\
\text { more degrees of freedom and the study has a small } \\
\text { sample. }\end{array}$ \\
\hline $\begin{array}{l}\text { Alkahtani } \\
\text { (2013) }\end{array}$ & $\begin{array}{l}\text { GE per } \\
\text { capita }\end{array}$ & $\begin{array}{l}\text { GDP per } \\
\text { capita }\end{array}$ & \begin{tabular}{|l|} 
SVAR, \\
impulse- \\
response \\
analysis \\
1993 - 2011 \\
(quarterly)
\end{tabular} & $\begin{array}{l}\text { The multiplier } \\
\text { is } 0.56\end{array}$ & $\begin{array}{l}\text { - The study checked for unit root but did not conduct a } \\
\text { cointegration analysis to discover any possible long- } \\
\text { run relationships between the variables and moved } \\
\text { directly onto VAR/SVAR estimations with the first } \\
\text { differences of the variables. } \\
\text { - It is unclear whether the reported coefficients are } \\
\text { multipliers or elasticities. }\end{array}$ \\
\hline $\begin{array}{l}\text { Looney } \\
\text { (1989a) }\end{array}$ & $\begin{array}{l}\text { GE, } \\
\text { GI, } \\
\text { GDE }\end{array}$ & \begin{tabular}{|l} 
PC, \\
GVAMI, \\
GVAMA, \\
GVAC, \\
GVAD, \\
GVAS
\end{tabular} & $\begin{array}{l}\text { TSLS } \\
1960-1985\end{array}$ & $\begin{array}{l}\text { GE on PC: } \\
0.09 \\
\text { GI on GVAMI: } \\
0.0057 \\
\text { GDE on GVA: } \\
-0.011 \\
\text { GDE on } \\
\text { GVAMA: } \\
-0.455 \\
\text { GDE on } \\
\text { GVAC: } 0.16 \\
\text { GDE on } \\
\text { GVAD: } 0.084 \\
\text { GDE on } \\
\text { GVAS: } 0.03\end{array}$ & $\begin{array}{l}\text { - The study used time series data but did not examine } \\
\text { its unit root and cointegration properties. Therefore, } \\
\text { one can argue that the study might suffer from } \\
\text { spurious regression issues. We think addressing } \\
\text { these issues was particularly important for this study } \\
\text { as it was designed for use in policy analysis. } \\
\text { - If the post-estimation test results were reported, } \\
\text { then readers could get information on Gaussian } \\
\text { conditions, stability and other properties of the } \\
\text { estimated equations. }\end{array}$ \\
\hline $\begin{array}{l}\text { Looney } \\
\text { (1988) }\end{array}$ & $\begin{array}{l}\text { GE, } \\
\text { Gl, } \\
\text { GDE }\end{array}$ & \begin{tabular}{|l} 
PC, \\
GVAMI, \\
GVAMA, \\
GVAC, \\
GVAD, \\
GVAS
\end{tabular} & $\begin{array}{l}\text { TSLS } \\
1960-1985\end{array}$ & $\begin{array}{l}\text { GE on PC: } \\
0.09 \\
\text { GI on GVAMI: } \\
0.0057 \\
\text { GDE on GVA: } \\
-0.011 \\
\text { GDE on } \\
\text { GVAMA: } \\
-0.455 \\
\text { GDE on } \\
\text { GVAC: } 0.16 \\
\text { GDE on } \\
\text { GVAD: } 0.084 \\
\text { GDE on } \\
\text { GVAS: } 0.03\end{array}$ & $\begin{array}{l}\text { - The study used time series data but did not examine } \\
\text { its unit root and cointegration properties. Therefore, } \\
\text { one can argue that the study might suffer from } \\
\text { spurious regression issues. We think addressing } \\
\text { these issues was particularly important for this study } \\
\text { as it was designed for use in policy analysis. } \\
\text { - If post-estimation test results were reported, then } \\
\text { readers could get information about Gaussian } \\
\text { conditions, stability and other properties of the } \\
\text { estimated equations. }\end{array}$ \\
\hline
\end{tabular}




\begin{tabular}{l|l|l|l|l|l}
\hline \begin{tabular}{l|l} 
Looney \\
$(1986)$
\end{tabular} & GE & PC & $\begin{array}{l}\text { GSLS } \\
\text { 1960 - } 1979\end{array}$ & $\begin{array}{l}\text { - } 0.44 \\
\text { its unit root and cointegration properties. Therefore, } \\
\text { one can argue that the study might suffer from } \\
\text { spurious regression issues. We think addressing } \\
\text { these issues was particularly important for this study } \\
\text { as it was designed for use in policy analysis. } \\
\text { - If post-estimation test results were reported, then } \\
\text { readers could get information about Gaussian } \\
\text { conditions, stability and other properties of the } \\
\text { estimated equations. }\end{array}$ \\
\hline
\end{tabular}

\begin{tabular}{|c|c|c|c|}
\hline \multicolumn{4}{|l|}{ Notes: } \\
\hline GDP & Real gross domestic product & GI & Real total government investment \\
\hline $\mathrm{Y}$ & Real non-oil gross domestic product & GDE & Real government defense expenditure \\
\hline GVAMI & Real gross value added in mining & GEE & Real government education expenditure \\
\hline GVAMA & Real gross value added in non-oil manufacturing & GHE & Real government healthcare expenditure \\
\hline GVAC & Real gross value added in construction & GHUE & $\begin{array}{l}\text { Real government housing and community } \\
\text { amenities expenditure }\end{array}$ \\
\hline GVAD & Real gross value added in distribution & GAGE & Real government agriculture expenditure \\
\hline GVAS & Real gross value added in services & GCONE & Real government construction expenditure \\
\hline OAG & Real agriculture output & GTE & $\begin{array}{l}\text { Real government expenditure on transport, } \\
\text { storage and communication output }\end{array}$ \\
\hline OHE & Real healthcare output & GEDE & $\begin{array}{l}\text { Real government economic development } \\
\text { expenditure }\end{array}$ \\
\hline OCON & Real construction output & GHDE & $\begin{array}{l}\text { Real government human development } \\
\text { expenditure }\end{array}$ \\
\hline OT & $\begin{array}{l}\text { Real transport, storage, and communication } \\
\text { output }\end{array}$ & SGE & Share of total government expenditure in GDP \\
\hline GE & Real total government expenditure & SGI & Share of government investment in GDP \\
\hline GCA & Real government capital expenditure & SGC & Share of government consumption in GDP \\
\hline GCU & Real government current expenditure & SCA & Share of government capital expenditure in GDP \\
\hline GC & Real total government consumption & PC & Real private consumption \\
\hline
\end{tabular}

$\mathrm{SR}=$ short run; LR= long run

* Means that the reported coefficients are not directly provided in the papers but are calculated by the authors based on the information provided.

** The deflator was not reported.

*** CPI was used as a deflator. 
Notes

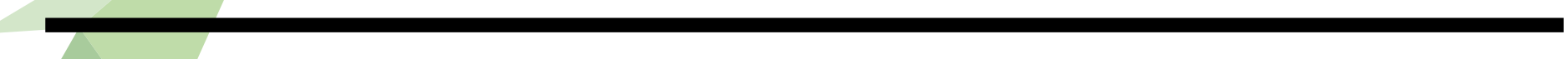




\section{About the Authors}

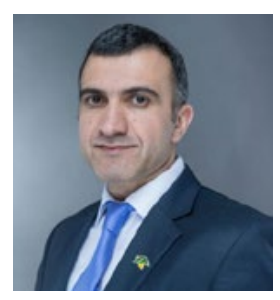

\section{Fakhri J. Hasanov}

Fakhri is a research fellow leading the KAPSARC Global Energy Macroeconometric Model (KGEMM) project. Previously, he was an associate professor and director of the Center for Socio-Economic Research at Qafqaz University, Azerbaijan. He has served as a deputy director of the Research Institute at the Ministry of Economic Development, and a senior economist at the Research Department of the Central Bank of Azerbaijan Republic. He received a Fulbright Post-Doctoral Scholarship and conducted a research on building and applying a macroeconometric model for policy analysis at the George Washington University. Fakhri is a member of the research program on forecasting at the George Washington University and the editorial board of the Asian Journal of Business and Management Sciences. His research interests and experience span econometric modeling and forecasting, building and applying macroeconometric models for policy purposes, energy economics with a particular focus on natural resource-rich countries.

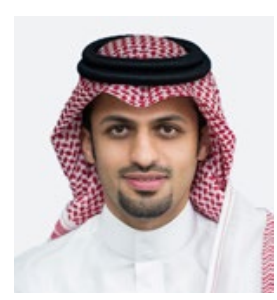

\section{Nader Alkathiri}

Nader is a research fellow at KAPSARC. His research interests include development economics, economic modeling, and natural resource economics. He leads a project exploring the role of sovereign wealth funds in promoting economic diversification in oil-dependent economies. Nader holds a B.Sc. in operations research, an M.Sc. in applied mathematics and computational science, and an MBA in finance.

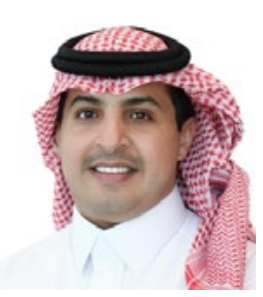

\section{Saad Ali Alshahrani}

Saad is Deputy Minister for Macro-Fiscal Polices at the Ministry of Finance, Saudi Arabia. Previously, he was an economist at the International Monetary Fund. He has served as a senior economic specialist at the Research and International Affairs Deputyship at the Saudi Arabian Monetary Authority. He has also been an assistant professor at Prince Sultan University, and a member of the establishment secretariat of the Gulf Monetary Council. Saad is a board member of the Saudi Economic Association and the International Islamic Trade Finance Corporation (ITFC). He is also a member of the Economic Policies Committee (EPC) at the OECD, and a member of the Financial Stability Committee. His research interests and experience encompass macroeconomic and fiscal policy, economic growth and development, public finance management, and econometrics. He received a B.S. in mathematics, and two M.Sc. degrees in statistics and economics, and a Ph.D. in economics. 


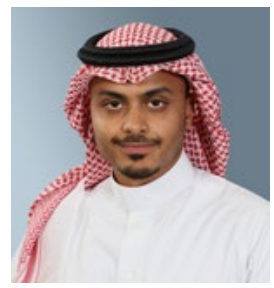

\section{Ryan Alyamani}

Ryan is a senior research analyst in the Energy and Macroeconomics program with a particular interest in natural resource economics and developing energy and economic models. Ryan holds a B.S. degree in mechanical engineering from Mercer University.

\section{About the Project}

The objective of this project is to provide an integrated framework for managing oil wealth in oil-dependent economies to achieve economic stability and sustainability. Oil-dependent economies rely on oil revenues to finance government expenditure. Oil-dependent economies face three major issues:

Oil revenues are highly volatile and uncertain.

Oil is a non-renewable resource. Therefore, it provides unsustainable revenue streams.

The oil industry is capital-intensive and generates fewer jobs than other manufacturing industries.

Reducing an economy's dependency on oil by developing other sectors within it can help to mitigate these issues. Stabilization funds can help counteract oil revenue volatility by stabilizing government expenditure in the face of oil price fluctuations. Sovereign wealth funds address the risk to the economy of oil depletion by generating sustainable sources of income in other sectors. Other objectives of these funds include improving intergenerational equity and isolating the economy from the negative macroeconomic effects associated with oil revenues, such as the so-called 'Dutch disease.' 
INAPSARC

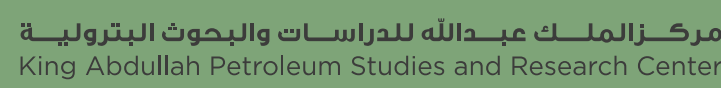

www.kapsarc.org 